\title{
The Female Victim
}

\author{
Whose Story Is Written on Her Dead Body? Exploring the Gender Politics of \\ Writing Female Victims and Their Traumas
}

Crime novels are either narratives of investigators or narratives of criminals rarely are they narratives of victims. While the murderer and, subsequently, the detective in some sense write their stories on the victim's body, the victim, often conventionally female, seldom gets the chance to tell her story. If she does, her tale risks being hijacked by the audience as pornographic spectacle, especially if it is one of sexual violence (Du Toit 2005, 257-258). Reading crime fiction through the lens of the female victim, thereby foregrounding her traumas as well as the potential for violence inherent in the representation of femaleness, is therefore a novel approach. My analysis of the female victim is based on a selection of contemporary South African crime novels that not only give unusual prominence to the female victim, but do so with a view to emphasising via fictional narration the real crimes that South African women suffer. The authors thereby become the female victims' advocates. I contend that, in so far as they give narrative shape to the female victim's story, these crime novels can be read as trauma novels that function to testify to and process through fiction the trauma of past and present real violence against women. At the same time, this fictional reworking of trauma constitutes a political act, as it exposes and revises - and at times reiterates - gendered and racial assumptions about women as victims, and of women's suffering and its representation in a local, South African - as well as in a global, generic - context. This raises some important questions. First, to what extent is it possible, within the generic frame of crime fiction and with a focus on the female victim - both as dead body and as survivor - to write against empirical gender violence? Secondly, can this be done in ethical as well as gender-revisionist ways that do justice to the victim's own trauma, in ways that have the potential to counterbalance the danger of sacrificing the female victim anew in narrative? For possible strategies, if not answers, I will examine Finders Weepers (2014) by Penny Lorimer, Blessed Are the Dead (2012) by Malla Nunn and Margie Orford's Clare Hart Series. Before doing so, however, I will discuss the complexities inherent in 
writing the female victim in a South African crime novel and then suggest a theoretical approach. ${ }^{1}$

\subsection{The Female Victim in Crime Fiction and in South Africa}

Closely looked at, but not seen, the victim is both the spectacular beginning of the crime novel and its invisible centre. Gill Plain calls it the "deep structural irony" within the crime fiction genre that "the body' is both crucial to and yet often overlooked by the fictional process" (2001, 12). Martin Edwards perceives a move in the genre's treatment of the victim from a mere "cipher" and a "signal for a battle [...] between murderer and sleuth" during the Golden Age (1999, 478 ) towards today's "realistic depiction of those destroyed by crime" (479). Kathleen Gregory Klein argues that, in the course of a crime novel, the victim becomes less visible and fades almost into irrelevance, as "the narrative of investigation supersedes the narrative of crime" $(1995,173)$.

The victim shares this paradoxical position of invisibility despite high visibility with people of colour. Beginning with W.E.B. Du Bois, African American authors have repeatedly problematised the experience of the racially different subject as simultaneously attracting and deflecting the gaze, and being rendered invisible in the process (Steffen 2012, 195, 199). The arrival of feminist crime writing in the 1980 s and 199os brought with it an attention to female victimhood, especially in relation to sexual violence. Its major concern, according to Priscilla Walton, was with "the thorny issue of the relationship between woman's victimization and woman's agency," between her "endangerment and empowerment" $(2013,23)$. However, this tension was mostly negotiated through the figure of the female detective and the female detective as victim. ${ }^{2}$ In addition to her relative invisibility, the female victim comes with the baggage of the gender stereotype. Traditionally, the role of the victim is ascribed to women. Klein goes so far as to argue that "the victim - or [...] 'the body' in the library - is, despite biology, always female" $(1995,173)$. She finds support for this in the victim's occupying the second position in the criminal/victim binary and in the victim's gradual disappearance as, in the course of the investigation, the detective gains ascendancy over the criminal.

1 This chapter is derived in part from an article published in Current Writing: Text and Reception in Southern Africa October 2017, copyright the Editorial Board Current Writing, available online: http://www.tandfonline.com, DOI: 10.1080/1013929X.2017.1347424.

2 Until very recently, this focus on the female detective and her agency has been reflected in feminist scholarship on crime fiction (Walton and Jones 1999, Kinsman 2010, to name but a few examples). 
In the South African context, when we leave the crime site of the fictional for that of the real, the female victim is no less fraught. In a society long characterised by violent crime, the need to acknowledge the victim seems crucial, whether this entails a symbolic acknowledgement of those female victims who are dead and can no longer bear witness, or an acknowledgement of those victims who survive to tell their stories. The need to listen to a woman's story of the pain inflicted, to trust its truth value, could be considered a precondition for reconciliation, for reparation as well as for individual healing. Indeed, these are the foundational assumptions of the TRC. As the experience of South African women with the TRC has made evident, attending to victims and their narratives of trauma is not a gender-neutral practice. Writing the female victim is a risky endeavour - made even riskier when she is a woman of colour - since the necessity of protecting the victim from further, secondary trauma is set in difficult relation to the necessity of exposing injustices and precipitating change. The necessity of acknowledging her as a victim is opposed to the danger of fixing her, almost as a cipher, in victim status and of perpetuating racial and gender stereotypes of invisibility, passivity, subordination and inferiority. ${ }^{3}$ Moreover, as the historian Svenja Goltermann reminds us, the very category of "victim" is by no means a stable one. Who is defined as a victim in the first place, and who is not, depends on power structures, as well as the victim's personal perception $(2015) \cdot{ }^{4}$

\subsection{Theoretical Preliminaries}

Chris van der Merwe and Pumla Gobodo-Madikizela point out that "'translating' trauma into the structure of a language and a narrative is a way of bringing order and coherence into the chaotic experience" $(2008,15)$. For this reason, I propose to read the crime novels examined in this section as trauma novels and the victim's story as both a - necessarily mediated - testimony of gendered "truth" and a feminist-political act. This approach is informed both by postcolonial literary trauma theory and by scholarship on the gendered dimensions of bearing witness following the work of the South African TRC. In addition, I will focus on interrelated questions of ethics and aesthetics in representing female victims. This part of my discussion is informed by Elisabeth Bronfen's studies on death and femininity and by Michele Aaron's work on the ethics of spectatorship.

3 With regard to speaking about rape, Du Toit, drawing on Plato and Derrida, alerts us to the notion of language as pharmakon, as having the capacity to act as either medicine or poison, a capacity that cannot be controlled easily (Du Toit 2005, 257).

4 Goltermann bases this last point on Ashraf Kagee's research on political prisoners in South Africa. The prisoners see themselves not only as victims of the apartheid regime, but as heroes in the struggle for democracy $(2015,89-90)$. 
At this point, I want to clarify what I mean by the term "postcolonial literary trauma theory" and highlight three pivotal respects in which it overlaps with South African feminist criticism of the TRC. The term "postcolonial literary trauma theory" does not exist per se, nor does it refer to a unified theoretical body of ideas. Instead, I use it to draw together various postcolonial critics of the early scholarship on trauma in the field of literature, such as Michelle Balaev, Barry Stampfl, Irene Visser, Ewald Mengel and Michela Borzaga. ${ }^{5} \mathrm{Al}-$ though these scholars' views vary considerably, ${ }^{6}$ all of them criticise the Eurocentricity of the early trauma model and are sceptical of its ability to account for trauma as it is represented in literature emerging from postcolonial situations. In particular, they take issue with the Caruthian notion of trauma as unknowable, unclaimable and unrepresentable (Balaev 2014, 1). Mengel and Borzaga state:

Notably, Western theorists of trauma like Cathy Caruth, Dori Laub or Geoffrey Hartman, whose theories are informed by deconstruction, have treated trauma as an unclaimed (and unclaimable) experience. By putting trauma at the centre of a theory of representation, their melancholic vocabulary is one marked by notions of absence, holes, deferral, crises of meanings, unknowing, and dissociation, in this way precluding any possibility of healing for individuals or entire nations.

2012a, xiii, original emphasis

While Balaev concedes that "amnesia, dissociation, or repression may be responses to trauma," she does not consider them "exclusive responses" (2014, 6, original emphasis). She shares the claim of postcolonial literary trauma theorists that traumatic experience can be known and claimed, and that transformation

5 Michelle Balaev coins an umbrella term for the diverse body of criticism of classic trauma models, namely "the pluralistic model of trauma" (2014, 3). Barry Stampfl uses the term "revisionist trauma studies" (2014, 37). Both Balaev (2014, 1-8) and Stampfl (2014, 15-22) offer a detailed discussion and criticism of the work of Shoshana Feldman, Dori Laub, Cathy Caruth and other early trauma scholars. Stampfl further provides an overview of the revisionist literature, starting with Dominick LaCapra and Ruth Leys and extending beyond the postcolonial perspective (2014, 16; 36-37). Irene Visser offers a criticism of the early scholarship as well as an overview of existing work from a specifically postcolonial perspective $(2011,2015)$.

6 While some critics consider it necessary to decolonise, or adapt and modify the tenets of classic trauma theory in order to render it fruitful for postcolonial situations, Mengel and Borzaga seek to incorporate existing but long-excluded studies by thinkers such as Frantz Fanon, Albert Memmi and Ashis Nandy, which link trauma, colonialism and racism (2012a, xii-xiii). 
and healing are therefore possible, at least to some extent. In her reading of South African literature, which draws on Mengel's and Borzaga's essays, Visser demonstrates that the collective traumatisation of generations of South Africans is neither "an unclaimed nor unclaimable experience, but rather is reclaimed in narrative" and that "the characters find ways of coming to terms with the past and moving on with their lives in new and creative ways" (2014, 117). In a similar vein, Fiona Ross alerts us to the ways in which the TRC framed female victims of apartheid as "unable to move beyond the experience of violence," thus freezing them in victimhood (2003a, 92). This is in stark contrast to her own research, which testifies to women's ability to recuperate and to remake their lives not only for themselves, but for those around them (Ross 2003a, 20, 139-141, 161).

As well as according victims the potential for healing and transformation of the traumatic experience, postcolonial literary trauma theory and South African studies on women and the TRC agree on two more pivotal points. First, they call for a widening of the scope of trauma to include the effects of longterm structural or systemic violence emanating from conditions such as patriarchy, colonialism or apartheid. ${ }^{7}$ Christopher J. Colvin (2008, 230), Mengel and Borzaga (2012a, xi) and Stampfl $(2014,24,37)$ all point to the need to move away from an event-based notion of trauma in situations like the South African one, not least because it "'medicalises' and 'privatises' suffering" and thereby "remove[s it] from the world of political and moral debate" (Colvin 2008, 230). In her critique of the TRC's narrow focus on bodily harm, Ross concurs:

The physical experience of pain is but a part of a far wider destruction. By focusing too closely on bodily experience, we run the danger of failing to attend to the experiences of which women speak. A focus solely on the body and its violation fixes experience in time, in an event, and draws attention away from ways of understanding of that experience as a process that endures across bodies and through time.

Ross 2003a, 49, my emphasis

Besides offering a limited account of women's suffering and eliding harmful social consequences, such a reductive understanding of trauma reinscribes

7 "Structural" or "systemic" violence refers to the systematic continual and continuing harm to individuals that results from social, economic and political structures. Colonialism, patriarchy, apartheid, poverty, sustained police harassment, persistent discrimination and humiliation, confiscation of land, constant surveillance or racially formulated education are often cited as examples of this type of violence in a South African context (Ross 2003a, 21-22; 30, Van der Merwe and Gobodo-Madikizela 2008, 10-11, Colvin 2008, 230). 
gender differences, Ross argues (2003b, 176). This point is emphasised by Tristan Anne Borer, who notes that women have been shown to suffer from structural violence even more than men (2009, 1174).

Secondly, literary scholarship on trauma in the post-colony and studies on women and the TRC agree on the need to highlight victims' agency, resistance and resilience in the face of trauma. Colvin warns against ignoring traumatised individuals' coping strategies and resources, including local ones, as well as their capacity to assign culturally specific meaning to trauma $(2008,231)$. Similarly, Visser maintains that "agency and empowerment might need to be incorporated as modes of theorizing trauma's aftermath" (2011, 279). Balaev sees early trauma scholars as removing agency from survivors by "disregarding a survivor's knowledge of the experience and the self" $(2014,6)$, while Ross's research on the violations that women suffered during apartheid reveals how the TRC's definition of women as victims tends to downplay their agency and resistance (Ross 2003b, 175). She, too, opposes a limiting view of victims that disregards women's other roles, resilience, survival strategies and agency amidst and despite suffering (Ross 2003b, 175).

The contribution of gendered criticism of the TRC to postcolonial literary trauma theory makes clear that gender matters when attending to victims and their trauma - be they real or fictional. The TRC's failure to uncover the full extent of women's sufferings under apartheid (Ross 2003a, b, 2008, Borer 2009) has had severe and lasting consequences for women. The women who did not testify were not able to take advantage of either the psychological support services provided to statement makers or reparation grants (Goldblatt and Meintjes 1997, 15-16). What is more, the widespread use of sexual violence during apartheid and the way in which it functioned as a weapon of war have been left unacknowledged. Worst of all, the perpetrators of these crimes have not been held accountable (Borer 2009, 1179). This unacknowledged legacy of past violence has led to an acceptance of violence against women in the present (Goldblatt and Meintjes 1997, 14) or, in Borer's terms, to "a culture of sexual violence in South Africa" rather than "a culture of rights" (2009, 1180). Ultimately, the way in which patriarchy served as a means of supporting racial discrimination has remained off the record (1180). While the nexus between trauma, memory and narrative has been the object of considerable attention in South African literary studies more generally, ${ }^{8}$ so far, postcolonial literary trauma

8 Contributions include the essay collections edited by Jaspal K. Singh and Rajendra Chetty (2010), Mengel and Borzaga (2012b) and Chris Andrews and Matt McGuire (2016, Section II: South Africa) as well as individual essays by Chris van der Merwe and Pumla Gobodo-Madikizela (2008, chapters four and five), Mengel (2009), Rosalind C. Morris (2011) and Visser (2014). 
theory - let alone with a focus on gender - has not been applied to an in-depth reading of South African crime fiction. This is surprising, given the fact that the enactment, re-enactment or at least recapitulation of a traumatic event, and often also the quest for "truth", are part and parcel of the crime genre. What is more, the genre's serial nature lends itself both to a fictional compulsive repetition of trauma and/or a working through of trauma. In his essay on trauma and genre in the South African novel, Mengel lists crime among the genres with an "inherent suitability for and special affinity with the representation of trauma" $(2012,146)$ and notes the common concern with truth-finding of both crime fiction and the South African TRC (16o-162). These connections will be explored further in my analysis of the crime novels of Penny Lorimer, Malla Nunn and Margie Orford.

\section{Boniswa Sekeyi and Lulu: Witnesses of Systemic and Sexual Violence in Penny Lorimer's Finders Weepers}

"I want to charge him," said Lulu. Her voice tightened.

She had been fiercely insistent on reporting Nyumbane, despite my warning that she in turn might be accused of instigating a flirtation.

$[\ldots]$

"What I will say is just the truth," she stated. "If people want to doubt, then they can doubt, but I will know. Miss S always told us to be honest."

LULU in Finders Weepers (156-157)

Miss S - Boniswa Sekeyi - is the principal of Girdwood College, a onceillustrious mission school in South Africa's poverty-stricken Eastern Cape, and the murder victim in Penny Lorimer's debut detective novel Finders Weepers. Her promising student and protégé Lulu falls prey to South Africa's education system and to sexual abuse. This chapter argues that, with Boniswa and Lulu, Lorimer pursues alternative approaches to writing female victims and their traumas within the frame of the crime genre. Not only does she resist existing representational practices of violated female bodies that deflect from the individual woman's pain, but she effectively addresses the structural violence of the South African education system and the ways in which it perpetuates gender inequality and gender violence.

In Finders Weepers, the I-narrator Nix Mniki, who is of mixed Xhosa/German parentage and a broadcast journalist, recounts the story of her investigation 
into the murder of her mother's best friend's daughter, Boniswa Sekeyi, newly appointed principal of Girdwood College. Nix's narrative is interspersed at regular intervals with the emails Boniswa had been sending to her American friend and mentor, Dr Pauline Wilson, from the moment she took over as principal of Girdwood College until the day before she died. Boniswa's emails provide a kind of fictional documentation of the state crime that is South Africa's education crisis. Together with the journalistic piece on the history of South African mission schools that concludes Finders Weepers, the emails lend a touch of the documentary to Lorimer's detective novel. They are testament to an urge on the part of the author to supplement the crime fictional "truth" with a more factual kind of truth. The "documentary turn", or the "desire (or need) to document," as Leon de Kock terms it, is commonly found in South African literature following the TRC (2016a, 179).

Published in 2014, Finders Weepers is Lorimer's debut adult detective novel. Previously, the White author had written school textbooks, short stories and young adult crime fiction. Born in England, Lorimer has lived in South Africa from the age of six months. A trained actress, she has been a union administrator and a PA to an archbishop, and has had various jobs in the media. She is currently working in the education sector (Lorimer 2015, par. 2). In my discussion of Lorimer's novel, I will focus first on its ethics and aesthetics of representation. Next, I will look at the testimonial content of Finders Weepers and its gendered implications.

\section{1}

Absent in Presence - Present in Absence: Representational Practices of (Dead) Female Bodies

The case of journalist-investigator Nix Mniki is triggered by a female victim true to genre conventions. Boniswa Sekeyi is missing and her mother fears the worst. It is the absence, rather than the presence, of the female body that marks the opening of the detective novel. Only a few pages later, however, we read the first of Boniswa's many emails to her American friend. Boniswa's sudden, spectral and unmitigated presence as murder victim through her own voice in her emails comes as a complete surprise to readers of crime fiction. I argue here - following Elisabeth Bronfen - that, by rendering Boniswa as both absent and present in the narrative, the author stages sacrificial representational practices, as femininity in stereotypical representation is characterised by simultaneous presence and absence $(1992,1995)$.

An intriguing absence is contained in the novel's very title. Derived from the adage "finders keepers, losers weepers," the title encloses a lacuna. Ending on "weepers," it merely echoes the "keepers" that are lost, thus emphasising what is not actually there, what is missing. For Nix, Boniswa has been an absent 
presence all her life. Their mothers are close friends, but the girls, although of almost the same age, have never met, as Boniswa grew up with her grandparents and later went abroad to study. Boniswa has always been a rather begrudged barometer in Nix's life: "As long as I could remember, my mother had held up Princess' daughter as the epitome of intellectual brilliance, a model of all that a truly dutiful child should be" (Lorimer 2014, 8). Understandably, Nix harbours no kind feelings for Boniswa, whom she resentfully names "Perfect Example Girl" or "PE Girl" $(9,10)$. To Nix, Boniswa is the one who is already lost before she actually finds her in more ways than one. By the time Nix finally encounters Boniswa's dead body (about halfway into the novel), Nix has paradoxically come to feel that she knows her and experiences her loss. Through her investigation, Nix has discovered a young woman whom she might actually have liked, and Boniswa in death becomes somebody she has come to admire and sympathise with. Even in death, Boniswa is there and not there, hidden in plain sight. Boniswa's dead body literally remains hidden in the midst of the frenzy of Girdwood College - precisely where Nix has come to look for her, but fails to see her for a large part of the novel. With reference to Bronfen's work, I will show how Lorimer's simultaneous absenting and presenting of the female victim and her body can be read as a reflection of representational practices of both femininity and death. Viewed in this light, what is literally missing in the title - "keepers, losers" - is a nod to the presence/absence specifically of women.

Taking a semiotic, aesthetic and psychoanalytical perspective in her work on femininity and representation, Bronfen shows that in stereotypical cultural representations - and the female victim is such a stereotype - woman is always a representative of something other than herself and hence not represented as a subject $(1995,412)$. Bronfen bases her claim on Teresa de Lauretis's differentiation between woman and women. The stereotypical woman is the object of representation, whom we look at. She is the purpose and origin of male desire and, as such, a construction. Women on the other hand are real, historical, physically existing women in De Lauretis's understanding. Woman and women do not coincide, yet women cannot be defined outside this discursive formation (410). While woman is pervasive as a signifier, what she signifies is not women. In representations, woman is present precisely in absenting real women. She is a representative, a proxy, a lacuna, her body a screen. Bronfen thus cautions us always to ask what ideological purpose lies behind the extinction of empirical women in the process of representation (420). Whose norms and whose interests are represented by woman, and what is it that she actually signifies (421)? If read psychoanalytically, cultural representations for Bronfen become collective symptoms, moments where suppressed material finds expression. 
As such, representations become leftovers, traces of what has been relegated to the unconscious, of what otherwise is unspeakable or unacceptable (425-427). According to psychoanalytically informed work by feminist film scholars, the woman in representation becomes a means to negotiate male sexuality - the position of the spectator being coded as masculine. It is assumed that, when the male spectator looks at a woman, he sees a castrated version of his own body. The female body is a reminder of loss and evokes feelings of threat and anxiety in him. However, he also sees a maternal body reminding him of a primordial, now lost, state of wholeness. According to Lacanian logic, this female body offers comfort to the male spectator at the same time as it sets his desire in motion, as he futilely attempts to regain this state of wholeness and unity (429-431). Since woman thus signifies both threat and safety, Bronfen terms her position an impossible, if not uncanny one: woman stages male rule ${ }^{9}$ and its impossibility at the same time (432).

Importantly, besides being coded as male, the spectator is coded as White. In her reading of W.E.B. Du Bois's concept of the veil, Therese Steffen shows how the veil, in the eyes of the dominant White viewer, negates the individuality of the person of colour, silencing and transforming him or her into a mere screen $(2012,190)$. If whatever woman signifies is not about her as a subject, such that her subjectivity is completely effaced, the woman of colour is doubly effaced in representation..$^{10}$ As Bronfen notes in her seminal work on death and femininity, "death is at work in the cultural construction of femininity" $(1992,208)$. She argues that, in representation, femininity and death function in analogous ways. Like femininity, death is ungraspable and lacks any empirical object: "Placed beyond the register of images that the living body can know, '[d]eath' can only be read as a trope, as a signifier with an incessantly receding, ungraspable signified, invariably always pointing back self-reflexively to other signifiers" (54). Bronfen demonstrates how representations of both femininity and death culturally work to "appease the threat of real mortality, of sexual insufficiency, of lack of plenitude and wholeness" (xii). The death of a woman thus becomes a "social sacrifice" (181), aimed at arresting in representation what cannot be arrested in reality - i.e. the dual threat of femininity and mortality - so as to preserve cultural norms. In the case of the death of a woman

9 Bronfen uses the German word "Herrschaft", which means male dominance, but also male rule and male control.

10 Chandra Talpade Mohanty bases her critique of Western feminist theory on De Lauretis's distinction between woman and women. She sees Western feminists as producing the "Third World Woman", an arbitrary construction that discursively colonises "the material and historical heterogeneities of the lives of women in the third world" (1984, 334). 
of colour, we can add, the sacrifice becomes a twofold one, stemming from the added threat of the racially other. It is this theoretical frame that helps to explain why real women's testimonies of sexual abuse are so prone to being appropriated by the audience as pornography. As Louise du Toit observes, "The attempt to represent an experience of female pain with the aim of fighting or stopping it, [may be] hijacked by an audience who reads it [...] as a spectacle of male pleasure" (2005, 257-258, original emphasis). Fiona Ross recounts the example of a woman who testified before the TrC. While she spoke out about the many different harms that she had suffered, one of which was sexual violation, she found herself framed by the TRC solely as a victim of sexual violence. This was reinforced by subsequent media reports that exploited the very graphic details of her testimony (2003a, 82-92), in effect positioning her through the sexual violence wrought upon her female body. Here woman is clearly revealed as a culturally circulated construct. Real women and their complex pain remain invisible.

Besides mirroring this simultaneous presence and absence of femininity through the figure of Boniswa, Lorimer draws attention to the inherent dangers for a victim who publicly speaks out about her sexual violations through the Xhosa girl Lulu. When Lulu, a student of Boniswa's and a survivor of sexual abuse by a well-known teacher, is about to address the church congregation, Nix warns readers of the risks that she is taking. Nix, the I-narrator, tells us: "Lulu rose [...] [h] er white choir robe gave her a look of radiant purity, but I felt my hands gripping each other in my lap, fearful that all she would do was open herself to disbelief and rejection from her neighbours" (Lorimer 2014, 229). For the duration of Lulu's public testimony - which is conveyed in direct speech - the tension and uncertainty as to its effect on the audience is palpable. Only once the listeners acknowledge Lulu's testimony as truthful and express their determination to fight this crime can Lulu and Nix - and, by extension, we reader-spectators relax: "They believed her. I let out a breath I seemed to have been holding for aeons" (230). Setting a counter-example to both exploitative representational practices and to the South African reality, which more often than not sees sexual offenders walk free, Lorimer has Lulu's testimony protected by the audience and acknowledged for what it is, resulting in the arrest of the perpetrator.

In representing the dead victim Boniswa, Lorimer offers two more resistant practices. First, she makes Boniswa resist the White male gaze and thus prevents her from functioning as a signifier that preserves the dominant norm.11

11 It is important to note that the "male gaze" can be adopted by anyone. "Male" here denotes an exploitative gaze that is originally coded as masculine, but can be adopted by spectators of any gender. 
Secondly, she features the victim's own voice via her emails. The way in which we first get to see her is through Nix's eyes. Nix is alerted to the presence of Boniswa's dead body by cawing crows jostling around it and by the smell of decomposing flesh. Stepping closer, she notices insects and then finally sees this:

As I parted the foliage a black buzz of flies lifted off some dark, swollen, disgusting thing. I reeled back and heard myself whimper [...] again, I squatted down and peered through the tangle of twigs and branches. First I saw a large-faced watch with a broken brown leather strap. Then a square-bladed garden spade. Finally, hair still woven in neat, intricate braids. There was no room for even the slightest doubt.

LORIMER 2O14, 136-137

What we see here is nothing but fragments. First, there is the flesh, which cannot yet be identified as human. In fact, Nix is hoping that it belongs to an animal carcass. Then we see the watch, which a neighbour later confirms to be Boniswa's: “I always tease her with her man's watch. She says she needs it to be big so that she is never late" (137). With the watch, gender comes into play, but in unconventional ways: for the neighbour, it is a man's watch, while for Boniswa it is a sign of professionalism. Next, we see a gardening tool, which may or may not be the murder weapon. Finally, there is the victim's braided hair, which serves as a racial marker. Only now is it confirmed: this is a Black female body. Nix's gaze narrows down, through a process of gradual accretion, ever more closely on to the specific human femaleness of what she discovers. And yet, we do not actually see Boniswa, not now and not later, when she is examined by a woman doctor. This is both a logical continuation of Lorimer's tactics of making us aware of the absence of the female subject, and a way of shielding Boniswa's dead body from the preying male gaze that is in search of reassurance. Fragmentation as a strategy here does not serve to fetishise the female body in order to disavow its threatening quality; rather, it functions to resist feeding the White male gaze.

Lorimer troubles this male gaze in a second way: namely, by having her victim "speak" beyond her death, beyond victimhood and beyond the confines of Nix's crime narrative. Boniswa's emails to her American friend are interspersed among and visibly set apart from the detective's account, appearing in every second or third chapter. For us as readers, therefore, Boniswa is present through her emails not only independently of Nix, but much earlier than for Nix. Nix retrieves the emails only once she finds Boniswa's laptop and manages to access her email account, about one third of the way into the novel. Because there are 28 emails in total, they carry substantial weight. They make 
Boniswa a prominent presence inside and outside the detective's account and thus arguably function to break the White male gaze and to work against the effacement of Black femininity. Moreover, Lorimer's strategy has ethical reverberations. Boniswa's emails interrupt the crime narrative at regular intervals and thereby serve as an "artful reminder" to the reader of his/her ethical involvement in the representation of violence to others. According to film scholar Michele Aaron, taking pleasure in unpleasure, or in the suffering of others as a spectator, can be ethical only if "the spectator's removal and innocence with regard to the spectacle" is challenged $(2007,92)$, only if "the cinematic contract that sustains the safety of the spectator, licensing a safe indulgence in the unreal, with the promise that it is only temporary" (92) is broken. One way to break the cinematic contract for her is through so-called "artful reminders" (94). If we apply Aaron's cinematic concept to readers of crime fiction, the email-voice of the victim that interrupts and disrupts the crime narrative can perform this function. It removes the distance between the reader and the pain of the victim that is being represented on the page. Through Boniswa's emails, we readers learn long before Nix about her problems with her poorly performing teaching staff. We can therefore rule out the possibility that Boniswa has simply forgotten to inform her colleagues and her mother that she is on leave from school much earlier than Nix can. This, and the information about the dismal state of the South African public education system we receive, propels the reader's own ethical judgement. If we read Aaron alongside Bronfen, we can extend the argument further. The artful reminder then also serves to make tangible the reader's complicity with the gendered practices in representation, with the way in which women are sacrificed. It allows for an alternative gaze on the female victim that does not sacrifice her anew in representation.

To sum up, Lorimer must be credited for finding means to sustain her focus on the trauma about which she seeks to testify. Nevertheless, Boniswa remains invisible to some extent. In her emails, she gives voice less to her own pain than to the way in which her students, the wider Girdwood community and, indeed, the country are suffering as a consequence of the education crisis. Boniswa thus becomes a "secondary victim", which is problematic, particularly because she is a Black woman. Here, Lorimer may be repeating a pattern for which the TRC was heavily criticised: eliciting testimonies from women who speak as mothers and as wives and who concentrate primarily on the sufferings of their family members, remaining silent about the violence inflicted on themselves. In fact, this is another recreation of the absent female victim. As much as Boniswa's emails are testament to her agency, they recreate her, at least to some extent, as the invisible Black female victim, who serves as a screen for 
a story that points to a larger social ill and away from the trauma of her own death. ${ }^{12}$

\subsection{A Testimony Uncovering Gendered Aspects of Structural Violence in State Education}

The story that is partly written on Boniswa's dead body by Nix, the investigatorjournalist, and partly recounted by Boniswa herself in her emails testifies to "the full horror of the effects of apartheid on the education of Black South Africans, which is something we have still not managed to correct" (Lorimer 2015, par. 7). Although the provocative subject of female pain - which Lorimer does not limit to sexual violence - is addressed in Finders Weepers, the narrative's main concern is with the less spectacular but historically traumatising effects of South African state education. These are mainly detailed in Boniswa's emails. Her account of the shabby, dirty, dilapidated buildings that she finds on her first day at Girdwood, with their broken stairs and windows and empty flowerbeds (Lorimer 2014, 14-15), read like a description of the current state and bleak outlook of South African education. Besides other shortcomings in the school's facilities - non-existent toilets and libraries, and a dearth of books, textbooks, photocopying machines and computers - the teachers themselves and their under-performance are described by Boniswa as a major obstacle to quality education. Not only do they lack methodical training and adequate qualifications for the subjects that they teach $(64,85)$, but they have a serious attitude problem, lacking both passion and interest $(64,85,93,117)$. Rampant absenteeism of teachers and students due to the shortage of transport and food, alcohol and sexual harassment further contribute to low performances and high dropout rates, as do poverty, HIV and teenage pregnancies $(21,64,132$, $148,189,252,274)$. The appalling state education that Girdwood exemplifies in the post-transitional present is repeatedly contrasted with the college's former glory. Before apartheid, Girdwood was a famous mission school. As "the leading school for blacks in the whole country" (9), it produced many of today's leaders. Boniswa and other voices in the novel blame Girdwood's decline on several factors: the apartheid legacy of Bantu education, the powerful teachers' union, which protects underperforming teachers, petty politics and a lack of government support $(64,93,117,204,257,297-299)$. The salience of Lorimer's account in present-day South Africa is emphasised when we recall the stance of two prominent South African public intellectuals, Hlumelo Biko and Alex

12 What is more, as a recipient of a relatively privileged education, Boniswa herself is sub-
jected to the trauma of South African state education to a lesser extent than her students. 
Boraine. Their analyses support elements of the narrative focus of Finders Weepers: namely, that the present flood of unqualified teachers is a legacy of Bantu education, ${ }^{13}$ which Biko terms an "intellectual genocide of indigenous South African people" (2013, 171). Boraine, too, points to the lack of training and/or commitment of teachers $(2014,115)$. This reinforces inequalities because state schools in poor areas, such as the one Girdwood is modelled on, are disproportionally affected. The influential South African Democratic Teachers' Union (Sadtu) prevents change. It "has protected the majority of teachers from the harsh realities of normal competition and has facilitated the retention of a large cadre of poorly trained, de-motivated teachers" (Biko 2013, 179). As an affiliate of the influential Cosatu - the Congress of South African Trade Unions - Sadtu participates in the ANC government. Since then President "Zuma needs their support and their vote, he is unlikely to act against them" (Boraine $2014,115)$. Thus, the systemic violence stemming from the legacy of Bantu education under apartheid has been actively perpetuated by the democratic South African government. "[W]ho knew," Biko accuses, "that under a black-led government, the chief casualties of bad policy making would be black children?" $(2013,187)$. Here the novel clearly succeeds in testifying to long-term damage and acknowledging the consequences of systemic violence, as called for by postcolonial literary trauma theory. While both Lulu and Boniswa suffer eventbased trauma when having their bodies violated, the novel demonstrates that these physical violations have their genesis in structural violence: Combined with the systemic violence of an unreliable criminal justice system and public health system $(251,246-248)$, and unleashed on a community that is already weakened by rampant HIV, addiction and fragmented family structures $(36$, 55, 77), the South African education system robs children of any occupational prospects. In this way, it sustains and cements racial and gender inequalities.

Lorimer can be credited for attending expressly to the gendered dimensions of trauma founded in structural violence. Both Boniswa's sharp analysis in her emails and Nix's findings in the course of her murder investigation expose the effect of structural forms of violence on gender equality and gender relations. Boniswa describes how teenage pregnancies and a lack of sanitation facilities at school lead to poor attendance and high dropout rates among girls, further limiting an already poor education and diminishing girls' prospects $(133,164)$. Lulu's story illustrates the particular impact of structural violence on girls. Losing both her parents and her brother (to AIDs-related illnesses, Boniswa

\footnotetext{
13 For an in-depth discussion of Bantu education and its continuing effects, as well as of the relative benefits of missionary schools, see Biko (2013, 171-197).
} 
presumes (176)) within one year leaves Lulu particularly vulnerable and at risk of sexual violence $(77,121)$. Her character exemplifies the claim made by research on women and the TRC - that women suffer from structural violence in specific and aggravated ways. In addition, Boniswa points out how systemic violence harbours violence against women. She views male violence as resulting from a lack of male role models and from the way in which mothers take out their anger at being deserted on their sons (55, 148-149). Her own death is framed in these terms. Her eventual killer, the 17-year-old Sizwe, "is one of the very few students who has the academic potential to get a place at university" (148), but he lacks a male role model and is thus insecure and desperate for peer acceptance, as Boniswa recounts in her emails. When Sizwe arrives at school drunk and belligerent, she loses her temper with him and sends him home (265). This makes him feel so angry that he later kills her. When Nix finds him as the killer, he tells her that "'she talk to me like I'm nothing. [...] I am a man. She must not talk to me like that." (280). Sizwe's reason for killing Boniswa is linked to gender. He kills a woman of authority for what he experiences as a humiliation of his masculinity. This is particularly ironic, since Boniswa in fact meant well. Perceiving Sizwe's potential, she wanted to make him head of the Student Representative Council and planned to help him to apply for a university bursary (148). Lorimer's explanation for Sizwe's violence against Boniswa falls within two of Du Toit's four interpretative frames, the "patriarchal-politics" frame and the "current social exclusion" frame. On the one hand, what Sizwe seems to resent here is "too much democracy," as Du Toit puts it $(2014,114)$ : the fact that a woman exercises her lawful authority over him, which in his eyes is an act of humiliation that requires an apology (Lorimer 2014, 280). On the other hand, his sense of degradation is depicted as originating in his own victimhood. As Boniswa's mother phrases it, "'His life was too hard. His mother was dead and I think his father beat him. He had no one to give him any direction, no values, no identity. A lot of the children here are like that. They have no self-control. They cannot grow up as they should because they are so focused on surviving [...]' " (285). By making us aware of Sizwe's own vulnerability as a young male, the novel puts the blame less on the individual Sizwe than on the larger structures responsible for his victimisation. While this serves to foreground the ways in which structural violence impacts on gender relations, and although Sizwe, through his suicide, pays a price, too, the novel nevertheless excuses Sizwe's violence, at least in parts. This is problematic if we follow Du Toit. It reduces Sizwe's accountability for the murder of Boniswa - which, after all, for him was a kind of punishment of a woman more powerful than him. There is a certain tension here between Lorimer's successful foregrounding of the traumatic effects of long-term systemic violence, the 
necessity for individual men's accountability and, possibly, the crime genre's preference for event-based death.

Finally, the novel rewrites female victims by depicting them as agents despite and against the oppressive structures. This is best exemplified by Lulu and her courageous decision to make her sufferings public, notwithstanding the risks of shame and vilification. Lulu is a victim, but she does not remain one. Finders Weepers manages to depict the agency, resilience and resourcefulness of the various victims, which allows them to go on beyond and in the midst of traumatisation. The novel is a story not just of Boniswa and Lulu, but of traumatised mothers like Nix's, who raise their daughters single-handedly (16-18); of mothers like Princess, who lose their children and still find the strength to go on and help others in need (214); of hard-working mothers who earn money far away from their children to sustain them (91-92) and of dedicated grandmothers who manage to support children and grandchildren on their tiny pensions (149). Although the victimhood of these women is by no means downplayed in the novel, the way in which they are endowed with agency prevents us from reading them as stereotypically passive and helpless. They are survivors, rather than victims. Boniswa, though, does die in the end - and she dies for having exerted her female agency and authority as a school principal. At the same time, she remains a powerful presence throughout the novel. Her emails, as well as the findings of Nix's investigation, are a testament to and celebration of her agency, her resolution to restore Girdwood to its former glory and her - in many ways, successful - mission to improve the education of her students. At the end of the novel, Nix decides to take over from her as foster mother of the orphaned student Lulu. Similar strategies of resistant agency are exemplified by Amahle, the victim at the centre of Malla Nunn's novel Blessed Are the Dead.

\section{Resisting Arrest: Amahle Matebula, Female Victim in Malla Nunn's Blessed Are the Dead}

From the day my daughter was born her eyes were on the horizon and what was beyond it. I should have kept her by my side but she did not like to be watched over. Now she is gone ...

NOMUSA in Blessed Are the Dead (16)

Grief-stricken Nomusa has to acknowledge both her daughter Amahle Matebula's death and Amahle's refusal to be contained by any set boundaries, be they racial or gendered. In making the 17-year-old Zulu Amahle the focus of her fictional investigation into the past in her historical detective novel Blessed Are the Dead, Malla 
Nunn works against arresting her victim in genre conventions. ${ }^{14}$ Amahle's dead body refuses arrest in a very literal way, being restlessly on the move throughout the novel. From the crime site, her friend Gabriel moves her to the hill where the detectives first see her. She is then taken to the town doctor's cellar for the postmortem, from where she is stolen by her half-brother Mandla and eventually buried in her father's kraal, sitting upright. According to Zulu belief, such a position prevents her spirit from finding rest (202) - as might her bus ticket to freedom, which remains valid after her burial $(254,299)$. This chapter aims to elucidate the novel's revisionist potential. I argue that Nunn erodes the sacrificial male detective's gaze on Amahle's dead body, thereby revising representational practices and allowing us to see women beyond the construct of woman. By depicting Black women, specifically, as agents in the face of trauma, Nunn further revises practices of bearing witness to South African women's sufferings under early apartheid. ${ }^{15}$ This allows Nunn to fictionally revisit and work through women's multiple traumas of patriarchal and racial oppression during that time.

Blessed Are the Dead is the third novel in Nunn's Detective Emmanuel Cooper series. Set in 1953, it takes Detective Sergeant Emmanuel Cooper and his colleague Detective Constable Samuel Shabalala of the Durban Detective Branch to the farming hamlet of Roselet in the foothills of the Drakensberg Mountains, where they investigate the murder of Amahle Matebula. the daughter of a local Zulu chief. ${ }^{16}$ Nunn is an internationally renowned novelist, screenwriter and

14 Pan Macmillan Australia published Blessed Are the Dead as Silent Valley in 2012.

15 Although Nunn's account of apartheid in the early 1950s falls outside the time frame covered by the TRC, I still consider the scholarship on women and the TRC to be relevant because it reveals the gendered dimensions of bearing witness in general and sheds light on the mechanisms that silence women's agency and sustain gender inequalities in that process.

16 The novel is set in the early years of apartheid (Butler 2009, 17). In its 1948 electoral campaign, the Afrikaner National Party used the slogan of "apartheid", which soon rose to prominence. The slogan drew attention to fears of urbanisation of the country's Black population and job competition. After its victory, the National Party enacted a body of racist laws (often termed "petty apartheid") that were all in effect at the time the novel is set: the Population Registration Act (enforced racial classification into four categories: White, Coloured, Indian/Asiatic and Native), the Immorality Act (prohibiting any sexual contacts between white people and people from the other three groups) and the Group Areas Act (enforced residential segregation). The Reservation of Separate Amenities Act (segregated transport, cinemas, restaurants and sporting facilities) was enacted in 1953 (Butler 2009, 16-17). While it laid much of the groundwork, according to Butler, “'petty' apartheid legislation was not designed to reshape South Africa's structures of economic opportunity but was distinguished by its undisguised racial malevolence" (17). It was later, in the 196os, during "high apartheid" that social engineering assumed a comprehensive, qualitatively distinct scale (20). 
film director and has won numerous awards for both her writing and her films. She has published four detective novels in the Detective Emmanuel Cooper series, all of which are set in South Africa: A Beautiful Place to Die (2009), Let the Dead Lie (2010), Blessed Are the Dead (2012) and Present Darkness (2014), as well as the young adult novel When the Ground is Hard (2019). Her filmography includes Fade to White (1991), Sweetbreeze (1992) and Servant of the Ancestors (1998). Blessed Are the Dead, the novel discussed in this chapter, was nominated for the Edgar Award, was short-listed for an Anthony Award and a Ned Kelly Award and was a 2013 Publishers' Weekly Top Ten Summer Crime Read. Nunn was born and schooled in Swaziland (now eSwatini) before emigrating to Australia. She attended universities in Australia and America and currently lives in Sydney (Krimi-Couch 2016, par. 1, 3, Nunn 2010a, par. 6, Key West Literary Seminar 2016, par. 1-3). In my analysis of Blessed Are the Dead, I will begin by identifying the novel's ways of remembering and reworking trauma as both individual healing processes and political interventions. Next I will explore the novel's politics of representing the female dead body, especially its negotiation of the male detective gaze. I will conclude with a discussion of women's sufferings and resistance in the South Africa of the 1950s, highlighting the novel's importance as a testament to women's agency in the midst of trauma across colour lines.

\subsection{Acting Out and Working Through: Revisiting, Reliving and Revising \\ Trauma as Observer and Observed in Nunn's Crime Fiction Project}

Given that both the author's and the detective protagonist's backgrounds suggest at least a potential for trauma not dissimilar from those that are given narrative form in the novel, I argue that Blessed Are the Dead offers a space not only for testimony, but for the processing of trauma, ${ }^{17}$ which in this case enables the author to take a political stance. It must be noted that neither the author nor her protagonist Cooper testify about their own trauma in any direct way. Both are witnesses of other people's traumas, but, since they share certain similarities in background with the people they testify for, they can be viewed as implicated in it to some extent. In contrast, in Finders Weepers, neither the author nor the detective were directly subjected to the structural violence to which the novel bears witness i.e. the South African education system (Lorimer 2014, 238).

17 To some extent this can be said of the whole of Nunn's Detective Emmanuel Cooper Series. Since Blessed Are the Dead is the novel in the series which gives most prominence to female victims, my analysis focuses on this novel. 
Dominick LaCapra's notions of "acting out" and "working through" trauma are particularly useful for understanding the processes at work in Blessed Are the Dead, since both Nunn and Cooper engage in the process of "working through" trauma. LaCapra elaborates the Freudian notion of "working through" in his book Writing History, Writing Trauma. He relates "working through" to "acting out" as forms of remembering trauma in a way that reveals not only the implication of the one in the other, but "the implication of the observer in the observed" (2001, 141). Acting out, as LaCapra explains, is a repetitive, compulsive way of reliving the past trauma as if it were happening now, in the form of flashbacks, nightmares or a sense of being haunted by ghosts. This can happen to victims, as well as to secondary witnesses and observers (141-143). Working through, on the contrary, is a desirable process, a "countervailing force," insofar as "the person tries to gain critical distance on a problem and to distinguish between past, present, and future" (143). While the two processes are distinct, LaCapra sees them as intimately related. For example, both are based on repetition. While "[a]cting out is compulsively repetitive, $[\ldots][\mathrm{w}]$ orking through involves repetition with significant difference" (148). It is precisely in this difference in the act of repeating that not only the potential for healing, but the potential for feminist interventions and revisions lies.

Nunn's narrative project is closely linked to her own childhood and to her family's history. However, while she draws from this source, she also renders it with significant difference. In a radio interview, she states that she used childhood memories alongside oral accounts from her relatives as a basis for her Detective Emmanuel Cooper series (Nunn 2012a). Nunn was born in Swaziland, as a child of a racially-mixed marriage. At the time her novel is set, in the 1950s, Swaziland was a British protectorate, but economically it was dependent on South Africa (Butler 2009, 20). Apartheid policies did not apply in Swaziland, but, as in all of southern Africa at the time, varying degrees of de facto racial segregation were in place. As Nhlanhla Dlamini explains, the racial hierarchy placed people of European origin on top and people of African origin at the bottom of the social pyramid $(2007,150)$. People of mixed European and African origins, referred to as "EuroAfrican" or "Coloured" in Swaziland, occupied an intermediary space. Dlamini details how people of mixed racial origins were excluded from the social, economic and political life of the country (34). Nunn herself attended a boarding school for mixed-race children, and her parents lived in Durban for many years before emigrating to Australia to escape apartheid (Key West Literary Seminar 2016, par. 2-3, Nunn 2012a).

Because of her background, Nunn has first-hand experience of the degrading effects of racial discrimination and segregation. In an interview, she speaks about the courage that it took for her to tackle southern Africa in fiction. "One 
major obstacle to writing a novel about Southern Africa was the fact that I never felt 'at home' there. I was uncomfortable in my own skin because I wasn't white or black but somewhere in-between" (Nunn 2010a, par. 13). It was only after making a trip with her mother back to her home in Swaziland - which became the basis for her award-winning documentary Servant of the Ancestors that she "found the guts" to write the first Emmanuel Cooper novel. She maintains that this way of reconnecting with her ancestors "made me realize that I was (and am) an African woman" (par. 13). In her crime writing project, set in apartheid South Africa, Nunn, significantly, moves away from the documentary mode that she employed in her film work. While she continues to rely on factual knowledge and personal experience, she chooses to mediate it through fiction, albeit in a genre that relies heavily on the real. Repetition with difference in LaCapra's sense can also be discerned in the way in which she portrays the effect of apartheid legislation in her crime fiction, but refuses to reproduce its segregationist practices. Roselet's social network is highly complex and only appears to abide by the law. Nunn paints a cross-section view of this society, with the legally induced racial and sexual boundaries intact in the upper half of the painting and with a very different network of paths, connections and divisions in the bottom half. Throughout her series, Nunn is at pains to demonstrate the myriad ways in which individuals are interconnected and entangled with, similar to, influenced by, dependent on and complicit with each other, across the lines of race and gender set by the law. For example, Blessed Are the Dead features Karen Paulus, a White Afrikaner woman who speaks flawless Zulu and is in love with an English woman. A love of gossip unites the different racial groups as much as the common belief that "members of their own tribe were more trustworthy than outsiders" (Nunn 2012b, 94, 190). By emphasising such commonalities and transgressions of set boundaries, Nunn not only challenges segregationist practices, but repeats their traumatic effect with a difference. She works through in LaCapra's sense, combining the psychological with the political, and demonstrates how, by working through, one can become an ethical and political agent $(2001,144)$. Finally, Nunn performs repetition with a difference and feminist political intervention through her fictional reintegration of Black women into the historical record. Back in 1953, incidents of Blackon-Black violence were low-priority cases for the police (Nunn 2012b, 31, 168). This may have been especially true of Black female-on-Black female violence. "[T] he hard truth [was]: reputations were not built on solving black homicides" (39). White detectives called it "[p]icking up the garbage" (39). A murder such as Amahle's would have gone uninvestigated and unnoticed by the official records; the story of the resistance of a young Black woman would have been lost to memory, constituting one of the "myriad hidden experiences of women" 
referred to by Anne McClintock (1995, 313). Though mediated by genre conventions and time, Nunn's historical detective novel reintegrates Zulu women such as Amahle into the South African cultural memory. ${ }^{18}$

In a similar fashion, Nunn's protagonist, who shares his author's racially mixed origins, ${ }^{19}$ witnesses and investigates traumatic experiences that are not, or are only partly, his own. Working his cases confronts Cooper with alcoholaddicted husbands, dysfunctional marriages, domestic violence and forbidden interracial love, all of which have played a part in his own life.$^{20}$ What is more, the combat, violence, blood and death that are part and parcel of his job as a detective trigger his war trauma from his days as a soldier in World War Two. The war dead constantly haunt his dreams and come "to warm their hands at his fire" (Nunn 2012b, 174) as do memories of "firestorms or missiles or swollen rivers washing the dead out to sea" (74). Detective work for Cooper thus very much entails being implicated in others' traumas and acting out as well as working through his own. Returning from the war, "he'd switched soldiering for policing because he needed to create order out of chaos and to uphold some notion of good regardless of the consequences" (222). His job has not merely a restorative function, but a redeeming one: "He could do nothing for the war dead. This death on a Natal hillside, however, he could do something about" (17). Even though Cooper is not able - and probably never will be - to leave his traumatic past behind him completely, in the end the voices of the dead and memories that resurface in dreams, triggered by his investigation, help him to grow and find his family (309). Processes of acting out and working through can never be entirely separated in Blessed Are the Dead, and neither do they happen independently of the act of witnessing and testifying to the trauma of others.

18 In his essay on trauma and genre in the South African novel, Ewald Mengel credits the popularity of the historical novel in post-apartheid South Africa to the fact that this genre offers a means of rewriting and reappropriating history from various formerly neglected perspectives $(2012,147)$.

19 Cooper has an English mother and an Afrikaner father, but there is a possibility that he is part Cape Malay (Nunn 2012b, 123). In A Beautiful Place to Die, we learn that his paternal origins are contested. His mother had an affair with a man who was part Malay (Nunn 20o9, 354). With Cooper's convoluted lineage, Nunn deliberately disrupts apartheid's racial categories and counters any simplistic polarities.

20 Growing up a "white kaffir child" (Nunn 2012b, 35) in extreme poverty in Sophiatown, Johannesburg, Cooper was subjected to a violent father who was also an alcoholic. His father killed his mother because he thought "a half-caste shopkeeper had fathered his children" and was acquitted of manslaughter (Nunn 2009, 354). He and his sister were then adopted by a "staunch, God-loving Afrikaner family" (Nunn 2012b, 74). Later Cooper escaped to Europe to fight with the British military in World War Two. 


\subsection{Challenging the Power of Looking On: Contesting the Male Gaze}

"Amahle" means "the beautiful one" (Nunn 2012b, 15). This corresponds with her function in the novel as a "a looker", as somebody whose attractive physique draws attention. Based on Elisabeth Bronfen's work on femininity and representation, I argue that Amahle appears to feed the male gaze and to be arrested by it. At the same time, however, the control of the male gaze itself is undercut and called into question.

Unlike Penny Lorimer's female victim Boniswa, Amahle is not looked at by a female detective. Because Cooper is the main focaliser in the third-person narrative, it is through his eyes and investigation that we see Amahle, so it is important to examine exactly what Cooper's eye focalises and to what effect. ${ }^{21}$ Cooper and Shabalala are guided to Amahle's dead body by a maternal relative of hers and by the wailing sound of the grieving women who surround the corpse.

One of the women shuffled to the side to make a gap in the circle through which Emmanuel could approach the body. A black girl lay on the sweet spring grass, gazing up at the soft blue sky and the shapes of darting birds in the air. Her head rested on a rolled-up tartan blanket and tiny red and yellow wildflowers were scattered over the ground. Three or four flowers had fallen into her mouth, which was slightly open.

NUNN 2012b, 9

From her face, Emmanuel's attention next moves to her hands, arms and feet. He finds a small bruise on her inner thigh, but no visible injuries. Only when he rolls Amahle's body over does he spot a small hole puncturing her white dress, which is speckled with spots of blood (13). With Shabalala's attentive support, Emmanuel's gaze works slowly and methodically. Although pornographic detail is lacking, it is nonetheless a preying, objectifying gaze the gaze of the investigator scanning the body for clues. "Under normal circumstances [...] Emmanuel would have pushed aside the neckline of the girl's dress and checked for bruising on the shoulders and under the armpits" (10), but the presence of Amahle's relatives keeps him in check, so that all he can do is frantically read the dressed body and its surroundings for signs and take notes. Amahle's dead body is an object to be examined for clues by the detectives, a signifier. Moreover, Amahle's corpse, as pictured here, is an

21 Nunn states that she had to make Cooper male for plausibility's sake: in the 195os, police work was a male game (2012a). 
aestheticised death, beautified - in keeping with the meaning of her name. Absorbed into the natural world as she is, Amahle the individual is effaced. As woman, Amahle is a representative of something other than herself and, heeding Bronfen, we must examine whose norms and whose interests she represents (1995, 412; 420-421; see also my previous discussion of representational practices in Lorimer's novel). To begin with, as the object of a murder investigation, she serves to further Cooper's and Shabalala's careers in the police service. This case is going to get them "out of the dogbox and back in the kitchen" (Nunn 2012b, 306), as a relieved Cooper notices in the end. It also feeds Cooper's need for heroism. "Solving a homicide is the closest we come to being heroes. You'd have to be lazy or stupid to give up the chance" (77). However, this bolstering of male hegemony is more complicated than it first appears, since Nunn challenges or at least mitigates Cooper's exploitative gaze. First, he and his team display a high degree of self-reflection with regard to their own professional roles and explicitly acknowledge and empathise with different perspectives. This is exemplified by the Jewish doctor Daniel Zweigman, who understands why the child Gabriel would want to take revenge on him for cutting Amahle during the post-mortem (148-149). As Cooper notes, "Without the law and the promise of justice for the victims, Zweigman was just a charnel-house sawbones and he and Shabalala mere undertakers" (83). This is an artful reminder - to use Michele Aaron's term - that serves to qualify the predominance of Cooper's perspective. Secondly, by rendering Cooper as himself a victim, Nunn dismantles the hegemony of his gaze. The numerous flashbacks he experiences in the course of his murder investigation, especially when being confronted with the pain of others, leave him exposed and vulnerable. He is himself in crisis, his control vitiated.

Next to the male detective team, Amahle's male next of kin fight over the way in which her dead body is "represented," wanting to secure their norms and interests. With his nubile daughter's death, Chief Matebula has lost a prized possession, a commodity. Cheated out of his lobola (bride price), he makes Amahle's mother and sister suffer for it and punishes Amahle by burying her sitting upright like a criminal (201-202). This offends the men of Amahle's mother's clan, who in turn wage war against Chief Matebula. Amahle's burial place turns into a battleground (202-205). Her contested dead body becomes a pawn in a war between men: brothers and fathers fight for male sovereignty over her dead body. Like that of the detective, the familial power of her father and brothers over her body is disputed. As an alternative to Amahle's biological, patriarchal family, her self-chosen "adoptive brother" Gabriel Reed functions as a qualifier. Gabriel is Amahle's intimate friend and the youngest son of the influential English Reed family, Amahle's employers. Gabriel also 
claims Amahle's dead body, but he does so in order to care for, to protect and to commemorate it, as Cooper immediately understands (10-11). The White boy is mentally challenged yet highly intelligent, speaks Zulu better than English, has a pale blue and a dark brown eye $(161,205,210)$, is still childlike at sixteen and has been nick-named "Nyonyane" or "little bird" by Amahle. ${ }^{22} \mathrm{He}$ defies any categorisation and refuses to be caught up in the net of any patriarchal power. According to Ella Reed, Amahle saw herself as Gabriel's big sister. While "[a]ll the native men in the valley were after Amahle [...] she let Gabriel get close because he didn't want her that way. They made their own little world together" (271). When she is dead, Gabriel grieves for Amahle the individual, the soul sister, the fellow transgressor, the accomplice, beyond Amahle the object of desire, or woman. So, even if Amahle functions to sustain male hegemony, be it that of the detective or that of the patriarchal family, that hegemony is always already undermined by Nunn, constituting an unstable representational hold.

Cooper's Testimony of South African Women in the 195os: Patriarchal and Apartheid Violence Revisited and Resisted

Thanks to Cooper's gaze being undercut in its hegemony, it allows for a testimony of women's trauma. What is revealed are the effects for women of the systemic violence of patriarchy, particularly the institution of marriage, and the racial politics of early apartheid in rural South Africa in the 1950s. Remarkably, though, Cooper's testimony foregrounds female victims' agency, especially their transgressive agency and the ways in which they resist arrest resulting from violence. Across the boundaries of race and class, women are watched over and kept in place by their violent husbands. The English, middle-class town doctor Margaret Daglish has a bruised wrist (2012b, 36, 79), fears the alcohol-fuelled anger of her husband and says with regard to her marriage: "I am living in the dark" (222). Amahle's battered mother Nomusa, too, lives "in the shadow of the great chief" (66) who controls even who she is allowed to speak to (6o). Cooper sees these women in their sufferings, not least because he recognises his own broken mother in them, a mother he was unable to save from his father's violence $(53,66)$. Amahle's story, by contrast, is not framed as

22 Gabriel's illness is not specified. Several times he is called "befok" (Nunn 2012b, 137), which is crude Afrikaans for "crazy". The Zulu call his illness "ukuthwasa" (297), a disturbance of the mind. Gabriel is "a habitual runaway and thief" (139) and has a habit of "roam[ing] the hills by day and night, talking to the trees and the animals" (297). He can "outfox" watch dogs (138) and compulsively names and catalogues the world (214): people by their nicknames and plants and animals by their scientific names $(213,225)$. 
a narrative of brokenness, focusing instead on her active resistance to victimhood and to the precarity conveyed to women by marriage. Cooper's account reveals that the intelligent and independent-minded Amahle had been making secret plans to escape Roselet and her father's plans to marry her off to another local chief for twenty cows. What is more, the fact that as a Black woman she is doubly discriminated against does not necessarily turn her into a victim. The following contrast between Amahle and another Black girl with whom Cooper crosses paths makes this evident: "The National Party split the population into groups based entirely on skin color but Amahle Matebula and this meek Zulu girl with a half smile on her mouth had nothing in common but color. Amahle, the beautiful one, could detect male weakness and possessed the audacity to dream of a future bathed in bright, saturated colors" (252). More than anything, it is implied here, the difference lies in Amahle's "audacity to dream," in the ability to create a mental space in which the set gender boundaries are imaginatively transcended.

Even if the actual crossing of the boundaries fails, as in Amahle's case, the dream does not remain without effect on the way in which a woman perceives herself. In her work on the power of silence, Nthabiseng Motsemme points out that it is the retreat into an inner, imaginative space that allows the self to transcend existing "oppressive representations" (2004, 924), since it allows women to reimagine themselves (924-925). Motsemme perceives this as "an act of women's agency" (925). Moreover, any real or imagined transgression of the confines of gender and race in the novel renders the very existence of those confines visible. Significantly, Amahle, and other female victims Cooper testifies for bring patriarchal and apartheid law into focus the moment they transgress against it. Amahle knows full well the prospects of a married Zulu woman: "Married off young, a wife, then a mother and finally a widow without a home to shelter her children: Amahle had looked ahead, seen her own future and said no" (Nunn 2012b, 26o). How completely a Zulu wife is at the mercy of her husband is illustrated by Nomusa's impending fate. Blaming Amahle's murder on her, the chief threatens to cast Nomusa and her other daughter out. If that happens, "[n]o clan will give them shelter. They will live like ghosts out on the veldt, drifting and hungry" (258-259). Even in the case of the chief's death, there is no relief, for then, like cattle, his "wives and children will be split up and given to other chiefs or to men who can afford to keep them" (26o). Amahle, instead, was in pursuit of "life" (70), seeking to cross "the river," to use men "like stepping-stones to be skipped over lightly until you reached the other side" (70), rather than being exploited by them. In terms of race, too, for Amahle boundaries were there to be crossed. The Afrikaner Karin Paulus complains to Cooper how "[Amahle] forgot she was a kaffir and treated everyone 
like they were the servants" $(121) .{ }^{23}$ She even turned the power tables on the White male town constable Bagley in terms of race and gender. Knowing that he was sexually attracted to her, she satisfied him in order to then blackmail him for hush money and to ensure his silence about her escape $(238-244){ }^{24}$ This allowed her to buy herself a bus ticket to Durban and plan her getaway.

Amahle is not punished for her numerous transgressions. Rather, she is killed by a woman who is trying to overcome the same traumatising structures of hegemonic patriarchy, especially matrimony. Chief Matebula's fifth and youngest wife murdered Amahle to save her own skin. She killed Amahle in order to prevent the chief from collecting a bride price and marrying another wife with it, an action that would have resulted in her loss of privileges and - as a childless woman - of social security. (288). As a murder weapon, she chose a poisoned porcupine quill used by married Zulu women as decoration in their head coverings (14). Amahle was literally killed by a signifier of the institution she had been trying so hard to flee. Ironically, had her murderer known of her plan to run away, she would have had no need to kill her.

Besides Amahle's and her murderer's agency, Cooper's testimony includes White women's resistance to patriarchal hegemony. The town doctor Margaret Daglish refuses to "[p]lay [h]appy" (221) and keep up the façade of White, respectable middle-class life any longer, stepping out of her oppressive marriage to a violent ex-Air Force pilot turned alcoholic (230, 306). Ella Reed, an English woman, and Karin Paulus, an Afrikaner woman, manage to keep out of the institution of marriage - at least for the moment. By having a sexual relationship with each other, they secretly undermine the patriarchal hold of Ella's brother, "a South African king of the veldt" (90), and Karin's father, as well as the class divisions between English and Afrikaner in South Africa. Ella further attempts to undermine her brother's power by anonymously reporting Amahle's murder to the Durban police. Given that Amahle was employed by the Reed family, Cooper views Ella's act as akin to "lobbing a hand grenade into the family living room" (270). Overall, Cooper's testimony allows us to witness women's trauma, but neither we nor the victims themselves are arrested there. In LaCapra's terms, trauma is not made contagious; it is not simply repeated, it is worked through $(2001,142)$. LaCapra is adamant that, in an ethical sense, this does not equate to harmonisation of the past. Rather, "[i]t means coming to terms with the trauma, including its details, and critically engaging the tendency to act

\footnotetext{
23 A "kaffir" is a derogatory term for a Black person (Oxford English Dictionary 2017).

24 Amahle made Bagley break the law. As Cooper tells us, "a sexual dalliance with a black juvenile, no matter how brief, meant the loss of his job, his reputation and his family if it was made public" (Nunn 2012b, 243).
} 
out the past" (144). Nunn makes the traumatic conditions visible, while probing them for spaces of transgressive agency. She thereby complicates rigid constructions of victimhood, as advocated by feminist critics of the TRC.

The cultural and political achievement of Blessed Are the Dead lies in its revisiting and reworking both of a traumatic past and of representational and testimonial practices. Placing Amahle at the centre of her novel allows Nunn to focus not just on vulnerability, but on gendered and racial invisibility and effacement, historical as well as generic. Even though Amahle herself remains silent about her suffering, she is not silenced. Her dead body unsettles the male detective gaze and - like Boniswa's - "speaks" of women's traumas, without limiting them to sexual violence and without cementing women in victimhood. The nexus between trauma work and investigative work is also central to Margie Orford's detective novels. This time, though, the investigator is a woman.

\section{Serial Female Victimhood: Margie Orford's Clare Hart Series}

How must I tell my secret if I stay hidden?

PEARL in Daddy's Girl (36)

Pearl, daughter of gangster and serial rapist Graveyard de Wet, decides to tell her secret. She undresses in front of the camera, revealing the scars and cut marks inflicted by her father. Intent on not perpetuating her mother's and her grandmother's silence, she goes public, but is promptly subject to her father's brutal revenge. Whether or not she survives, whether or not her father becomes her graveyard, we never learn.

Pearl's scars, like the wounds of most female victims in Margie Orford's Clare Hart Series, speak of sexual violence. Like many of them, she remains arrested in victimhood, suspended between life and death, living yet not, unable to move beyond the frame that is the trauma of sexual violence, despite all the agency with which Orford invests her. Sexual violence is depicted by Orford as extending way beyond the singular event of crime. It is rooted in and perpetuated by a "culture of violence against women" that reaches back in time. Based on this understanding of sexual violence, Orford renders her heroine Clare's investigative work as a form of the trauma work that features in post-apartheid literature more widely. By attending to victims and becoming a victim herself, Clare uses her investigations to face and retrieve - even to repeat - the pain, to give it a narrative shape, and to alter how women relate to victimhood. In essence, Orford's storytelling is feminist political work. Pitting these ethical 
narrative achievements against the series' politics of representing the violated female body reveals complexities and contradictions, however. Orford employs a wide range of representational strategies, not all of which can be reconciled with her feminist project. Some succeed in drawing attention to and ethically engaging with women's sufferings. Others work to undermine this endeavour by not only sacrificing women anew in representation, but by distracting from their traumas.

Orford's Clare Hart detective novels quickly earned her the title "Queen of South African crime fiction". Born in London, Orford is a White writer who grew up in Namibia and South Africa. She left South Africa in 1988, subsequently living in London, Namibia and New York. On returning to Cape Town with her husband and three daughters in 2001, Orford "felt besieged by the extravagant violence of the place" (2010b, 186), especially the high levels of gender violence. They were the reason why she, as a journalist, started working on crime. Orford reported crime in order to "find the voices of the brutalised and the dead" (187), but soon became frustrated. As a journalist, she felt that all you can do is "list a never-ending series of facts" (187). She therefore turned to crime fiction, which allowed her to "at least start to scratch at the truth" (187), "the truth of violence, resilience or revenge" (191). Orford's crime fiction has earned her national and international acclaim and been translated into many languages. Besides being a successful crime writer, she is an award-winning journalist, a filmmaker, a writer of children's books, academic books, school text books and non-fiction, ${ }^{25}$ an editor, ${ }^{26}$ a university lecturer, a campaigner against sexual violence, a board member of PEN South Africa and the patron of Rape Crisis and the children's book charity the Little Hands Trust (Fletcher 2013, 196, PEN South Africa 2015, par. 11-15, Pretorius 2014, 7, Vale 2010, 6, Vincent and Naidu 2013, 50). My analysis is based on all but one of Orford's Clare Hart novels: Like Clockwork, originally published in 2006 (I use the 2010 edition), Daddy's Girl, first published in 2009 (I use the 2011 edition), Gallows Hill (2011) and Water Music (2013). I do not discuss Blood Rose (2007) as female victims are peripheral to the novel's main plot, which centres on male juvenile victims.

25 These include The Magic Fish (2012), The Little Red Hen (2011), Fifteen Men: Words and Images from Behind Bars (2008), Fabulously 40 And Beyond: Coming Into Your Power And Embracing Change (2006), Busi's Big Idea (2006), Dancing Queen (2004), Climate Change and the Kyoto Protocol's Clean Development Mechanism: Stories from the Developing World (2004), Rural Voice: The Social Change Assistance Trust, 1984-2004, Working in South Africa (2004).

26 She co-edited Coming on Strong: Writing by Namibian Women (1996) and Women Writing Africa: The Southern Region (2003). 
All the novels examined here feature the White private investigator-cuminvestigative journalist Dr Clare Hart as detective protagonist and give prominence to female victims. Each novel focuses on a particular aspect of violence against women, in line with Orford's claim that each of her novels is a response to a particular, real crime $(2013 \mathrm{~b}, 226)$. In Like Clockwork, businessman Otis Tohar sexually assaults, brutally murders and spectacularly exhibits the bodies of three beautiful young women along the affluent Cape Town waterfront. His fourth victim manages a counter-attack and is saved with Clare's help. While Tohar's murder motives are located in his own traumatic childhood and are thus of a personal nature, his crimes against young women are greatly facilitated by his associates, human traffickers for the flourishing video porn industry. Daddy's Gir ${ }^{27}$ centres on the abduction of Yasmin, daughter of Captain Riedwaan Faizal, head of the SAPs's Organised Crime and Drug Unit, a Coloured man and Clare's professional and romantic partner-to-be. Yasmin, whose disappearance is one in a series of disappearances and murders of schoolgirls, is finally rescued unscathed. The other young female victims are less fortunate: they all lose their lives through sexual violence and/or shootings in gang warfare. It transpires that Yasmin's abduction was instigated by Superintendent Clinton van Rensburg, a colleague of Riedwaan's, in order to force Riedwaan to take revenge on the members of the Numbers gang who have been ruining Van Rensburg's daughter's life. Like Otis Tohar's motives, Van Rensburg's are ultimately personal, but similarly dependent on larger structures that condone crimes against women. Orford locates these crimes primarily within Louise du Toit's fourth or "ontological-violence interpretative frame". While "past perpetrator trauma" (Du Toit 2014, 103 (first frame)) does play a role, Tohar's aim is to destroy the victims' worlds in an attempt to produce dominance $(118,120)$. The same is true of the male perpetrator in Water Music. In Daddy's Girl, Van Rensburg's violence, as well as that of the Numbers gang, is a message directed at other men in a (gang) war between men, which Du Toit sees as characteristic of the fourth interpretative frame. Of a different kind are the crimes in Gallows Hill, where Clare's murder investigation coincides with her documentary on slavery in the Cape. The death of Eva Africa leads to the discovery of a mass slave grave in Cape Town's Gallows Hill and of a female victim murdered 25 years previously, Suzanne le Roux. Clare's investigation of Suzanne's killing leads her to Suzanne's daughter Lilith, who lives in Cape Town under threat from

27 Daddy's Girl's narrative time precedes Like Clockwork's, even though it was published afterwards. It describes the beginnings of Clare's relationship with Riedwaan. 
her mother's murderer, Gilles Osman. His crimes, as well as the larger past and present crimes that come under scrutiny in this novel, are not of a sexual nature; rather, they point to a criminal web of politicians and business people. In her most recent novel, Water Music, Orford returns to sexual crimes against women and children, which she terms a modern form of slavery (2013b, 229). Under the pretext of religious chastisement, Noah Stern keeps women and girls imprisoned as his sex slaves on his secluded Paradys farm. His most recent victim is the beautiful young cellist Rosa Wagner. Although the novel revolves around the individual cases of Noah Stern's female victims, it suggests that crimes against children have assumed epidemic proportions in South Africa. As part of Clare's work for Section 28, an SAPS unit named after clause 28 of the South African constitution and set up to guarantee children's rights, she has created a "chart of horror" (Orford 2013c, 39), a map with a whole forest of red and black pins. The red pins stand for injured, the black pins for dead children.

As is evident from these plot summaries, Orford tends to generate hyperspectacularised crimes in her fiction. By doing so, she panders to the public obsession with crime that exceeds the facts of crime, as described by John and Jean Comaroff (2004, 801; see also "Introduction"). With regard to the facts of crime locations, for example, the Comaroffs report that the Cape Flats, "that high-density, low-income part of Cape Town contains six of the seven worst microzones in the country for both murder and attempted murder" (153). The Cape Flats figure prominently as a criminal location in Orford's fiction, but many of the crimes we actually get to witness in her narratives occur in more affluent and Whiter areas, where, according to the Comaroffs, the real crime rates are low even by global standards (153). However, the Comaroffs' findings confirm the prevalence of sexual violence in South Africa, as reflected in Orford's crime fiction. Although international comparisons are difficult to establish, the Comaroffs report that the country "[b]y most accounts [...] comes up first in comparative measures of rape" (155, see also "Introduction"). For this reason, I will begin my discussion of the Clare Hart series with female victims' testimonies of sexual violence.

Testifying to a Culture of Sexual Violence: the Stories Told by Scars on Women's Bodies

For Orford, it was J.M. Coetzee's novel Disgrace that "opened a space for [her] to think of writing crime as fiction" (Orford 2013b, 224). The epiphany came one cold Monday morning, when she was standing next to the raped and stabbed body of a twelve-year-old girl. Recounting that moment in a Cape Town mortuary, Orford notes that 
the crimes represented in Disgrace are, in essence, violent conversations between men about land, possession, revenge, and access to women. The bodies of women are, in a profound sense, incidental, the women themselves either silenced or inaudible. And yet, as Lurie insists, "There must be a niche in the system for women and what happens to them" (Coetzee 1999:98). I wanted to locate that niche.

$2013 \mathrm{~b}, 225$

Locating that niche and narrating the women's traumas is the task Orford sets herself as writer, intending to give a voice to, or at least to speak for, the otherwise "silenced or inaudible." In this way, her writing becomes an act of testifying - albeit, arguably, a paradoxical one, if evaluated against the backdrop of postcolonial literary trauma theory and feminist critical engagement with the TRC.

Despite giving unusual prominence to female victims in her crime fiction, Orford explores female agency mainly through the figure of Clare. It must be noted, with Sam Naidu, that "it is not only the detective figure that determines the feminist status of the text" $(2014,8)$. Orford invests her victims with substantial agency; however, by focusing on the traumatic moment, she fixes them not only in victimhood, but in that moment in time. Many of Orford's victims fight fiercely for their lives. In the hands of the killers, entirely at their mercy, their fates seemingly sealed, Teresa Angelo in Like Clockwork, Yasmin Faizal in Daddy's Girl, and Rosa Wagner and little Esther in Water Music all remain agents and fight to stay alive in situations that appear utterly hopeless. All of them survive. The same goes for Clare's twin sister Constance and Whitney Ruiters, two victims who not only survive but singlehandedly avenge the violations that they have suffered by killing the perpetrator, Kelvin Landman, in Like Clockwork (313-314). Another victim in the same novel, Nathalie Mwanga, as well as Pearl de Wet in Daddy's Girl, decide to speak out about the abuse that they have suffered over an extended period, while Lilith le Roux in Gallows Hill, severely traumatised by her mother's early disappearance, displays agency in her use of art as coping strategy.

Given that these women play an active role in their survival, it would be wrong to say that Orford portrays them as without agency, thus perpetuating the stereotype of the passive female victim. There are other criticisms that can be made of her approach, however. First, the survivors remain pitted against all those who precede them, of whose struggles we learn little and who have found death at the hands of the very same serial killers. Taking into account the sea of victims of similar crimes who populate the novels via Clare's documentary film projects, the parallels to other victims that she establishes in the course of each investigation, and the way in which, time and again, the 
epidemic proportions of sexual violence in South Africa are emphasised, the nine surviving women listed above appear like the chosen few. Secondly, the sheer impossibility of escaping victimhood is epitomised by the physical marks that it leaves. Strikingly, Orford's female victims have the stories of the violence committed against them literally and indelibly written on their bodies. Trauma in Orford's novels leaves physical traces inscribed in the female body, in the form of wounds, bruises, scars or brittle bones. In Like Clockwork, Kelvin Landman marks "his girls" (145) with an x-shaped tattoo (93), thus conferring victim and distinctive object status. Noah Stern's victims in Water Music bear his signature in the form of sjambok ${ }^{28}$ scars and signs of malnourishment $(150,183)$ while Lilith has her mother's death certificate - faked by her murderers, we later learn - tattooed on her body in Gallows Hill. " “[...] It's what made me," Lilith says (174). It made her an artist, mentored by her mother's murderer. And it has made her remain under his power. Clearly, Orford intends the visible signs of violence to be seen and acknowledged by the public, to be read (like a language), understood and made sense of by the trained eye and sharp mind of her female investigator. According to Caitlin Martin, the visible scars in Orford's crime writing mirror invisible psychological damage. For her, this points to the dissociation of or duality between mind and body that violence can inflict on human beings (2013, 110-111). Kate Every views the scars and tattoos in Like Clockwork as testament to the lasting effects of violence on victims and society as a whole $(2016,39)$. While she reads them specifically as stigmata pointing to the stigma (in its meaning of "shame" and "discredit") that is attached to sexual violence (36-37), she also finds them to be markers of shared visible victimhood, facilitating a community of victims (38). These are convincing arguments, but the fact remains that the victims will never be able to shed the perpetrator's stamp, making it impossible for them to move beyond the traumatic event. Despite functioning to draw attention to the huge injustice of these crimes, indelible scars are suggestive of lifelong victimhood, particularly if they mirror psychological damage. Victimhood here is reproduced and perpetuated, despite the best of intentions. In this, the novels reiterate the effects of the TRC, which, as Fiona Ross argues, tended to freeze victims as such (2003a, 92-93).

This framing and freezing of the survivors in Orford's novels as victims is underscored by the fact that we part with them rather abruptly at the end of the narrative, and often uncertain as to their ultimate fate. It is as if they are

28 A "sjambok" is a strong and heavy whip made of rhinoceros or hippopotamus hide, used in South Africa for driving cattle and sometimes for administering chastisement (Oxford English Dictionary 2017). 
made to function as sacrificial outcasts, hovering in a zone that is neither life nor death. For example, in Like Clockwork we leave Teresa Angelo safely ensconced in an ambulance and are taken back to witness Riedwaan's final struggle with the perpetrator in the subterranean tunnels. However, our gratification at Riedwaan's success in arresting Tohar is dampened by the film scenes of rape and mutilation of female bodies that continue to be played out on Tohar's screens - and, by implication, on many others all around the globe. Even if the individual, particular perpetrator is apprehended, his violent enterprise seems impossible to curtail and female victimhood is perpetuated. In Daddy's Girl, the last we learn of Yasmin is that her father has signed the document permitting her to embark on a new, safer life with her mother in Canada, but the other surviving victim, Pearl de Wet, remains in intensive care with life-threatening injuries (311). Lilith is similarly suspended between life and death in Gallows Hill: "sliced up like a halaal lamb" (341), she is awaiting the ambulance. ${ }^{29}$ Only in Water Music do we get to see the two surviving victims, Rosa and Esther, alive and happy six months after their spectacular rescue. Rosa is playing her beloved cello again, and they are able to scatter Esther's mother's ashes on the ocean (329). Through this symbolic act of release, they can let go of their victimhood and move on with their lives together. None of Orford's other female victims are able to leave the shadows of their victimhood, however. Victimhood, it is implied, is unlikely to end for women.

The indelible marks and tattoos on Orford's victims' bodies tell stories of a veritable war against women and girls, waged mainly with the weapon of sexual violence. Jessica Murray provides a detailed description of the gender violence in Orford's novels. She concludes that "Orford's Clare Hart novels succeed in representing the pervasive presence of gender violence in the lives of South African women and they give the lie to the persistent illusion that these instances of violence are aberrations that emanate from strangers" $(2013,76)$. However, Louise Vincent and Samantha Naidu question whether Orford paints a realistic picture of violence against women in South Africa $(2013,56)$. Real violence, they state, follows banal plotlines and "for many South African women their brutalisation is more mundane and as a result all the more baffling and debilitating" (55), although they acknowledge the value of Orford's depictions as a political gesture and counter-discourse. As Ross argues in her critique of the TRC, the limiting of violence against women to sexual violence - as understandable as it may be, given the extreme prevalence of sexual violence

29 "Halal" in this context means to kill an animal in the way prescribed by Muslim law (Oxford English Dictionary 2017). 
in South Africa - runs the risk of obscuring the effects of structural violence. Although Orford is less explicit in her exploration of structural violence and its effects on women than either Penny Lorimer or Malla Nunn, the role played by such violence is acknowledged in the stories written on the bodies of Orford's victims. Social structures are depicted as variously complicit in and/or facilitating, if not engendering, individual criminal acts. According to Murray, Orford's novels "suggest just how deeply gender violence is embedded in various social institutions, including the family, the state and the police force" (2013, 69). What is more, sexual violence as it is experienced by South African women can be characterised as a systematic continual and continuing harm resulting from what Tristan Anne Borer terms "a culture of sexual violence in South Africa" (2009, 1180, my emphasis). In her critique of the TRC, Borer notices the absence of applicants for amnesty for the crime of rape or other sexual violence before the TRC, and asks whether "raping women was simply not deemed a serious enough crime to warrant opening oneself up to public exposure" (2009, 1179). Helen Moffett contends that this sentiment is widespread among men in South Africa $(2006,138)$, which tends to support Borer's claim that the failure of men to apply for amnesty for sexual crimes has had repercussions for the human rights of women beyond the Truth Commission period. Notably, the fact that "no one was held accountable for these crimes [...] may well contribute to a climate of impunity - which is the antithesis of a human-rightsrespecting culture based on respect for the rule of law" (Borer 2009, 1179). Such a climate, according to Borer, may explain why, arguably, "[a]t the moment [...] rather than a culture of rights, there is a culture of sexual violence in South Africa" (Borer 2009, 1180).

Whatever the limits of fictional efficacy, Orford must be credited for depicting this "culture", ${ }^{30}$ its pervasiveness and the fact that it is sustained by men from all walks of life, independent of their social class and skin colour. She exposes the social complicity that allows for the culture of impunity criticised by South African feminists. As Teresa, the surviving victim in Like Clockwork is quick to notice, the film featuring another woman being gang raped that Tohar forces her to watch "had been through post-production. Someone had watched it before her, had seen whatever she was going to see, had edited and tweaked it. Teresa wouldn't be here if this person had said something, had done something" (296). Like Clockwork portrays trafficking women as a lowrisk, high-return investment (36). Women are also a relatively risk-free means

30 In her analysis of Daddy's Girl, Elizabeth Fletcher also points to this "culture of abuse and violence" (2013, 202-204). 
of enabling men to wage a psychopathic or religious crusade, as in Like Clockwork and Water Music, to rise up the gang hierarchy, to fight a gang turf war or to blackmail a colleague in the police, as in Daddy's Girl, or to protect their illegal business activities, as in Gallows Hill. ${ }^{31}$

Orford's crime fiction suggests that the culture of sexual violence does not stop at the door of the family. On the contrary - the family is depicted as damaged, disintegrating, dysfunctional, even lethal. Regardless of whether it is housed in wealthy suburbs or on the Cape Flats, the family fails to provide for and to care for children. It is not only a violent place of destruction and death for girls and women, but the breeding ground for an even more violent next generation of men. Change, Orford seems to imply, must be bottom up, beginning in the family. In the few visions of new family forms that she offers, she envisages a move away from the patriarchal family. Pearl de Wet in Daddy's Girl regards a total breaking of family ties as the only option for her daughter Hope. She has given her child up for adoption and "[n]ow her name is Hope Pennington. Her mother's a lawyer who lives with another woman in a nice, smart flat. Two mommies. Completely safe" (149). Water Music is suggestive of a future for the strong emotional bond between Rosa and little Esther born out of shared suffering. Rosa's fading grandfather and Esther's maimed brother, who are literally in the same boat with them in the novel's final scene, may well be part of that alternative family arrangement (329). Yet when Riedwaan asks Clare - their three-week-old son Ishmael in her arms - if she wants to marry him. Clare refuses politely: "'Marriage. Being two, becoming one. That's a step too far' " (330). Despite Orford's hopes, however, the queer family, the family of survivors, the rainbow family, will find it difficult to thrive as long as structural violence persists. Before the non-violent, nurturing South African family can materialise, a good deal of working through of the pain of the female victim is required.

\subsection{Breaking the Cycle of Trauma: Writing and Investigating Crime As Trauma Work and Politics}

Orford's focus on the victim in her fiction turns her crime writing into a privileged (in its dual meaning) site of engagement with trauma. Nowhere does

31 Despite her focus on sexual violence, Orford does not explore the issue of sexual violence against men, as has been done by K. Sello Duiker in his novel Thirteen Cents (2000), for example. The issue of sexual violence against men in prisons is alluded to just once, in Like Clockwork, when Riedwaan maliciously reminds Tohar that a dislocated shoulder will be "the least of your worries, where you're going. A handsome fellow like you is going to have lots of fun" (310). 
she dissect and exemplify the historical and psychological processes of facing and working through trauma more masterfully than in Gallows Hill. The novel's title refers to an actual location in Cape Town's Green Point where a mass slave grave was found in 2003 during construction work for a shopping centre and offices. ${ }^{32}$ I argue that, through the methods and strategies that Orford employs to retrieve and work through trauma in Gallows Hill, both writing and investigating crime become trauma work in Dominick LaCapra's sense. Trauma work, in addition to its psychological benefits, is in this way mobilised as a political act that aims to break the cycle of violence against women.

Like Lorimer and Nunn, Orford contests the traditional notion of trauma as an irretrievable and thus unsurmountable event, challenging proponents of trauma theory who regard traumatic experience as being beyond verbal expression. As the patron of Rape Crisis in South Africa, she notes:

I have observed that survivors who, through counselling, therapy and their own courage, could turn the obliterating experience of rape into a narrative - their own - would heal much faster, would reclaim their lost agency, their assaulted self, far more quickly. And they would be able to move on: they would be the same person, but also a profoundly different one.

$2013 \mathrm{~b}, 223$

As well as illustrating Orford's understanding of trauma as retrievable, these remarks are testament to Orford's awareness of victims' ability to "move on" after trauma in real life. However, as I have already shown, this is a step that she rarely permits her fictional victims to taken. In Gallows Hill, it is Riedwaan who, on digging up the bones of Cape Town's past, perceives the need to contain this trauma in a narrative. He is convinced that Clare is the right person to "find a way to tell this story $[. .$.$] the violence of it. Where these people came from"$ (24) so that "[i]t won't be so easy to hide" (25). Riedwaan's words point to the inseparability of the victims' stories from stories of historical perpetrators and stories of present perpetrators who wish to obliterate the past in the interest of business. This last point is particularly pressing given the fact that his crime scene is a prime building site that investors want to see developed. ${ }^{33}$

32 Ra'eesa Pather describes this and subsequent discoveries of slave bones in Cape Town, as well as the ensuing debates (2015). The same events are referred to by Mike Nicol in Payback (see my discussion of his novels in my chapter on female perpetrators).

33 "Who cares about people nobody even knew they'd forgotten" (Orford 2011b, 37), as the ruthless Hond Williams puts it. Hond ("Dog") is the new owner of the Gallows Hill building site. He "used to run Woodstock - tik, abelone, girls, guns, protection for brothels, later for politicians," Riedwaan remembers (34). 
The past is excavated in the narrative layer by layer. The process of retrieval starts with the death of a homeless woman, Eva Africa, on the Gallows Hill construction site. While Eva is suffering a heart attack, clutching the 30o-year-old $\operatorname{voc}^{34}$ slave disc handed down to her by her mother and grandmother, her hungry dog Jennie scavenges the ground and digs up a human bone (10). Called to the scene, Riedwaan digs deeper and discovers a mass grave of far older bones (18-19). In the course of further excavations, a small packing crate is found containing the remains of a woman who died approximately 25 years ago (30-31). The story of this privileged White woman, Suzanne le Roux, becomes the focus of Clare's investigation. With her name and the slave disc that Eva is clutching at her death, Orford establishes an obvious link to past female victimhood. At the same time, she effaces Eva as an individual. Eva is woman, who functions as a trigger for other stories. With her dead body comes the unravelling of a chain of bodies and bones of older victims, a catena that establishes links between various stages of Cape Town's traumatic past. Suzanne's body brings to life the violent days of apartheid in the 198 os, while the slave bones point to the crimes of slavery committed in the Cape 200 to 300 years earlier. Clare is determined to ascertain the identity and story of Suzanne in order to have Suzanne's trauma literally resurface in a potentially legible representation. Based on her skull, a forensic artist reconstructs the victim's face in a clay model. Not only does this facilitate her identification as Suzanne le Roux, but it leads Clare to her surviving daughter Lilith (144), who is her mother's "living image" (162). ${ }^{35}$ Even more faces are appearing all over town now: Lilith, who has been turning the pain of being abandoned by her mother into art, ${ }^{36}$ is advertising her current exhibition with posters picturing a face. "I've seen a face, a haunting face, it's up everywhere," Clare suddenly realises (151). In a process of gradual identification and piecing together of fragments of evidence, Clare is now intent on reconstructing Suzanne's life, particularly the days around her disappearance. Knowing that Lilith is her only key, Clare convinces her to "pick the lock" (310) to the painful memories of the night when her mother disappeared. It is at this stage that Clare's murder investigation turns into psychotherapy, into working through trauma. During an interview, which could just as well be a trauma

34 voc stands for "Vereenigde Oost-Indische Compagnie" (Orford 20nb, 68), the Dutch East India Company, which was instrumental in formalising the slave trade as an industry in the Cape.

35 The name Lilith, like Eva, is a woman-name in Teresa de Lauretis's sense. It refers to woman as a cultural construct and functions to absent empirical women (Bronfen 1995, 412).

36 Clare is eventually able to reveal that Suzanne did not disappear for political reasons, as her daughter was made to believe, but was in fact murdered. 
counselling session, Clare takes Lilith back to that night, when she was only four years old, and coaches her body and mind into remembering the details. Clare urges Lilith to "[f]ocus on the senses [...] [s]mell, taste, texture - those are the details that anchor the bigger things. They are the tiny things that jog the involuntary memory" (312). As additional "anchors" Clare uses the physical evidence she has so far gathered in the murder investigation, such as the stone inside Lilith's teddy bear and her mother's sketchbooks. Thus, fragment after fragment of memory is triggered and emerges either on paper - Lilith starts to sketch rapidly: "Colour and shape. Images returning from the other side of time” (312) - or as a sensory memory: “'How did you cut your feet, Lilith?' She shook her head. 'Think back,' said Clare, 'your feet. The pain in your feet -' 'Slippery', she whispered. 'The rocks, they were wet.' Clare waited. Lilith closed her eyes. 'She was with the man'" (315). Continuing her journey into that night, Lilith suddenly remembers how she felt a stone in her throat, " blocking the words. [...] It also blocked the pain.' 'And when it slips?' asked Clare. Lilith turned her scarred wrists upwards. 'You see, Clare, if I remember too much, maybe I'll lose the ability to speak again,' Lilith said. 'And I'm afraid that if I remember everything I'll die' " (316).

Retrieving trauma is a painful, terrifying and dangerous process that repeatedly threatens to overwhelm the traumatised. For Lilith, it is dangerous in yet another sense, as it will identify her mentor, art gallerist Gilles Osman, as her mother's killer. Constrained by the generic demand for speed as it is, Orford's account of trauma therapy is somewhat simplistic, while relying on metaphors like lock and key or likening the retrieval of trauma to an archaeological excavation is clichéd when compared with the slow toil of real psychotherapy. However, because the crime genre lives off and invokes the existential threat that the facing of trauma poses, it must be taken seriously as a platform to negotiate this threat. The genre is also well suited to treading the thin, often permeable line that separates acting out from working through. Orford lets the female detective, rather than the female victim, walk the final steps along this line, which is her investigation. If the female investigator Clare acted the therapist for the female victim Lilith, in the final stages of the process she herself acts and becomes the victim. It is she who finally turns the process into a clear working through, a working through that for LaCapra entails a "repetition with significant difference" (2001, 148). It is precisely in this difference in the act of repeating that not only the potential for healing and the resolution of the murder case, but the potential for interventions and revisions in the field of gender lies. In this difference, a space for gender transformation opens up. In the denouement of Gallows Hill, Suzanne's murderer Gilles Osman takes Clare captive. Intent on a precise repetition of his 
murderous act, this time with Clare as victim, Gilles leads Clare up to the quarry on Cape Town's Signal Hill, to the exact spot where he killed Suzanne all those years ago. On the way, Clare hears "the sigh of the grass against [her] legs" and instantly remembers the sounds in Lilith's gallery installation (343), confirming her suspicion that the evidence of Suzanne's murder "was all there, hidden in plain sight" (337) in Lilith's art. ${ }^{37}$ She now realises that she is being led along the same path as Suzanne, awaiting the same fate - namely, to be killed by Gilles with a black rock (344-345). By this time, Clare has completely identified with the original victim Suzanne. She is repeating, acting out the trauma of her violent death. At some point, though, "Clare's mind shifted gear, turned the terror back. [...] She was alive. And she knew this man. She knew him far better than he thought she did. She had a chance" (344). Clare the victim finds her agency - thanks to the knowledge that she has gained as a detective - and she laughingly mocks Gilles in the same way Suzanne mocked him, intent on triggering his memory and thus provoking him into an acting out, into replicating the same script. It works: "Osman stared at Clare. This woman was uncowed. Suzanne le Roux's laughter, her threats to expose him, were caught in the echo chamber of the quarry" (346). Clare keeps the upper hand and is now able to anticipate his next step. This, and her certainty that Gilles was caught unawares by the return of his memories, allows Clare to slip away from him, to hide in the darkness and to kick him over the edge of the cliff (348). Thus, in Gallows Hill Clare, the detective, takes the victim's place, reproduces the original victim's story and suffers some of the same violations, at the hands of the same perpetrator, only to add a twist of significant difference at the end: Clare the victim turns into Clare the perpetrator who kills in self-defence. Here, she embodies all three figures: the victim, the perpetrator and the detective.

The similarities between Clare and the victims whose interests she protects are made evident before this final scene up at the quarry. ${ }^{38}$ What is more, the same pattern of the detective turning into the victim and then into the

37 This scene is reminiscent of an installation by crime artist Kathryn Smith, who inspired Orford while she was working on Gallows Hill (Orford 2012, par. 15).

38 Clare herself is conscious of the resemblances between herself and Suzanne (48) and between herself and Lilith, who, like her, lost her mother prematurely (173). Furthermore, she instantly recognises her twin sister Constance's scars in Lilith's "symmetrical row of cuts and scars on the inside of her thighs" (170). These similarities are also perceived by the perpetrators - Basson sees both Suzanne's beauty and stubbornness in Clare (234), while Gilles hears both Suzanne's and Clare's mocking laughter at the same time (346) and even by Riedwaan, who first mistakes the injured Lilith for Clare (341). 
perpetrator is employed by Orford in her next novel, Water Music. ${ }^{39}$ Caitlin Martin and Sally-Ann Murray highlight a related incident where Clare becomes one with the victims of slavery during her visit to the slave quarters in Gallows Hill. They view Clare's physical reactions to the traumas that played out at this place as "an effect of emotional transference" $(2014,44)$ and read her response along ethical lines, as a resistant practice to "packaging exploitation as distant legacy, separate from current complicity and emotional claim" (43). For Antoinette Pretorius, on the other hand, Clare's ability to morph into victimhood is "an alternative mode of embodied investigation" (2014, 15), which, among other things, serves to value intuition in detection (13). Although Pretorius is right to see the way in which Clare steps into the victims' shoes as a feminist political strategy, it is important to emphasise that Clare becomes a victim but does not stay one, that she is a victim who regains her agency. For me, the moment of difference in Clare's repetition is crucial. Managing to transform the acting out of trauma into a working through facilitates both healing and the restoration of justice. Furthermore, it is a strategy that revises both gender and generic scripts of female victimhood. As a female victim herself, Clare taps into the cycle of violence against women, but is then able to break that cycle and reverse the roles. Not only does she thereby upset the victim-perpetrator binary, but she is able to achieve what is often not achieved in reality, certainly not by the TRC: namely, the arrest of the male perpetrator of violence against women. Thus, Every's reading of Like Clockwork as the re-enactment of a "counter-narrative to the closed nature of the TRC" (2016, 35) can be extended to Orford's novels as a whole. In Gallows Hill, for example, there is an emphasis on the incomplete or premature closure offered by the TRC. The novel provides us with a brief glimpse of the sufferings during apartheid and post TRC of Sophie Xaba, Lilith's other, "paid-for mother" (172). As Lilith's carer, Sophie, like countless other Black mothers, had to split her loyalty between the child she was paid to look after and her own son. The night Lilith's mother disappeared, Sophie's own house was burnt down and her own son Scipio disappeared (226). Sophie later tells Lilith, “'[...] That's why I could not help you, my Lily. I had to get home' " (225). Scipio's remains were never found: "Not even in the TRC. All the files were gone, they said. And no witnesses [...]'” (227). Sophie is still waiting for her son's bones, so

39 In Water Music, Clare follows Rosa's steps as part of her investigation only to end up, like and with Rosa, as Noah's captive. Intending to kill his victims, Noah is killed by Clare. On a platform servicing a water tunnel, Clare fights Noah and plunges a porcupine quill into his eye. They both fall into the water. While Noah drowns, Clare is pulled out and saved by Riedwaan (Orford 2013c, 325-327). 
that she can bury him (228). Orford offers a further hint at too-sudden closure of unfinished apartheid business in the figure of Jacques Basson, the former apartheid general with whom "nothing stuck" at the TRC. As he hastens to tell Clare, his case " "was dealt with by the TRC. Disclosed, forgiven, forgotten. Case closed, end of story. Nothing there [...]'" (235). It is against such socially pressurised closure, against a hasty closing of the books on the past, that Orford has Clare work, by reopening cold cases and by returning to, retrieving and working through past trauma. Orford demonstrates - albeit simplistically, perhaps - that detective fiction can function as trauma fiction. In the difference of the re-enactment that crime fiction produces lies political, revisionist potential. An important caveat must be added here, however. As a White, middle-class and well-educated woman, Clare is enormously privileged, and it is questionable how far the symbolic power of her agency can extend to less advantaged women. In South Africa, the women most affected by the trauma of violent crime are Black women who live in precarious socioeconomic conditions. Unlike Clare, these women are barely protected by public and private infrastructure. Viewed in this light, Clare's is a less inclusive political act than it might otherwise appear.

\section{$4 \cdot 3$ \\ “How Must I Tell My Secret If I Stay Hidden?” Representing Violence and the Violence of Representation}

Orford's success in using detective fiction as a means of attending to trauma cannot be properly assessed, however, without considering the ethics and politics of her aesthetics. Orford's sexy, violated female bodies have attracted a fair amount of scholarly attention. Christopher Warnes claims that, in her first three crime novels, Orford renders violence against women as a spectacle and thereby "runs the risk of reinforcing some of the very delusions that impede the feminist struggle she is claiming to wage" (2012, 990). Warnes does not develop this claim any further though. Focusing on Daddy's Girl, Elizabeth Fletcher recognises the fine line that Orford walks in her representations of the dead female body by "eliciting voyeurism and complicity on the part of the reader" $(2013,206)$. However, she regards this as a feminist strategy in order to draw "the reader into a state of collusion with the culture of abuse and thus a sense of responsibility" (208). Building on Fletcher's point, Naidu engages with the tension between the supposed generic requirement for sensationalised violence and Orford's stated and, in many ways, successful feminist agenda. Naidu reads Like Clockwork, Daddy's Girl and Water Music against the backdrop of écriture féminine and Julia Kristeva's notion of the abject. She argues that Orford represents the violated female body as abject - i.e. as both attractive and repulsive - and that, as a consequence, "the reader of crime fiction 
is interpellated as both voyeur and sympathizer, and the author and reader are both critic of gender-based violence and complicit peddler or consumer of a 'thrilling' genre" (2014, 71). She finds that the potential violence in Orford's representational practices might be read either as impeding her feminist project or as suggesting "a shared responsibility, a shared abjection on the part of author, detective, victim, perpetrator and reader" (78). Given the fact that the author is aware of the dangers inherent in representation, Naidu concludes by according Orford's representational practices a bona fide feminist status (78). Finally, in her reading of Like Clockwork, Every sees Orford as gesturing to the trope of the beautiful dead woman, but argues that this is counterbalanced by the agency of Orford's women (or, more precisely, some of Orford's women) $(2016,38)$.

Orford is well aware of the complex relationship between violence and representation. She states, "Edgar Allan Poe's formulation that the most poetic subject is the death of a beautiful woman holds true, and I am less and less convinced that one can short-circuit the erotic charge of the damaged female body, the building block of pornography, desire and crime fiction" (2013b, 227). In what follows, I will examine these tensions and contradictions in Orford's texts and their implications for the reader. I will show how widely Orford's treatment of the violated female body varies, both within and across her novels, and explore what this means for her feminist mission. Frequently, Orford sacrifices her victims anew in representation without granting the reader any opportunity to disengage from the narrative violence. At other times, her representational practices are highly self-reflexive and encourage readers to face their own complicities. On occasion, she effects an awkward merging of these strategies. Drawing on Elisabeth Bronfen's work on the cultural construction of femininity, Griselda Pollock's notion of aesthetic wit(h)nessing and Michele Aaron's concept of ethical spectatorship, I argue against any reconciliation of Orford's very different ways of dealing with the female victim. Contrary to Fletcher, Naidu and Every, I contend that Orford clearly undermines her own feminist project at times.

I will begin by highlighting where and how Orford's female victims are subjected to a decidedly heterosexual, predatory male gaze, which objectifies and thus efficiently effaces them as subjects and deflects from their traumas. The first dead female body in Like Clockwork, Charnay Swanepoel, "[...] lay spreadeagled on the promenade in full view of anyone who cared to look. Her face was child-like in death, dark hair rippling in the breeze. Blood, pooled and dried in the corners of her eyes, streaked her right cheek like tears. Her exposed breasts gestured towards womanhood" (3). Charnay's body is eroticised, as we look at her through the eyes of an elderly male passer-by. The bodies of the 
next two victims - Amore Hendricks (97) and India King (181-182) - are represented in similarly spectacular, sexualised ways. The man who discovers India's body even expresses his desire for her through touch. "[C]upping her breasts in his hands," he finds them "as full as the moon" (182) before he notices her slit throat and the fact that she is dead. Even Riedwaan and Clare, who generally approach female victims from a forensic perspective, can adopt the male gaze at times. When called to the scene of the murder of two schoolgirls in Daddy's Girl, Riedwaan notices that "[p]uberty had just settled, light as a butterfly, on the child's body - glossing and thickening her hair, swelling the exposed nipple" (28). Likewise, when Cassie reveals her discovery of the emaciated child she has been keeping warm under her fleece in Water Music, Clare's gaze immediately fixes on Cassie's "newly budded breasts" (16). And when Clare first meets the battered DesRay, she sees "the cold wind moulding her pink nylon nightie against her breasts, the tight curve of her belly, her bare legs. Bambieyes, full mouth, her bleached hair windblown" (115). At times, Clare becomes a voyeur, thus repeating "the lazy-gaze wander: lips, breasts, hips" (77) to which she knows she herself is often subjected by men. As Bronfen reminds us, such representational practices cater to heterosexual male desire and work to efface the woman as a represented subject $(1992,208)$. They seek to arrest the dual threat of femininity and mortality and thereby sacrifice the woman as a subject. This effect is intensified when the victim is a woman of colour. Although Orford's female bodies are always clearly gendered, they are seldom characterised in terms of race, at least not directly. However, given their names, the location of their homes and their socioeconomic status, we can infer that their racial backgrounds vary greatly. Orford wants to emphasise that gender-based violence cuts across lines of race and class, but her international readers, at least, who are possibly less well versed in deciphering the more subtle local markers of race, may misread this as a signal that race does not matter (any more) in South Africa. Moreover, leaving a female victim's racialised subjectivity to the imagination of the reader does not work to expose racial categories as constructs. Rather, it reinforces the problematic ways in which a woman's body functions as a screen and skips over the very real effects that racial categorisations have for South African women, not least in terms of vulnerability to sexual violence. ${ }^{40}$

40 Louise Vincent demonstrates that race "continues to have an often unacknowledged and unseen power to determine perceptions, experiences and relationships" in South Africa (2008, 1427-1428). According to the Comaroffs, "the incidence of crime and victimhood typically follows lines of race and class," with poor and Black precincts disproportionally affected $(2016,153)$. 
Griselda Pollock's critique of Alain Resnais' film Nuit et Brouillard/Night and Fog illustrates why Orford's representational strategy is irreconcilable with a real concern for female victims of violence. Taking her cue from Bronfen, Pollock criticises Resnais' politics of representation of women being killed in his 1955 film, which seeks to commemorate Nazi atrocities. She disapproves of the way in which he reproduces real photographs depicting naked/humiliated women and children just before they were killed because "[...] the relations between violence and eroticism are re-enacted in ways that deflect from the human trauma of what we are seeing. They stem from, and reabsorb the event into pre-existing tropes which use eroticised or humiliated femininity to deflect from the encounter with death" (2010, 853, my emphasis). If we apply this argument to Orford's use of the male gaze, two things become apparent. First, Orford performs and perpetuates the very sexual politics that she seeks to contest. Secondly, her practice diverts the reader from the very phenomenon to which she wants to draw attention: women's experience of pain. In other words, "the niche" for what happens to women, which Orford wants her crime fiction to point to $(2013 \mathrm{~b}, 225)$, is obscured, leaving the women inside unheard. Indeed, with regard to the complicity of the spectator (or, for that matter, the reader), Pollock emphasises that there is no escaping the sacrificial, (hetero-) sexualised gaze - what she terms "phallocentric voyeurism" (2010, 852). For "[...] our encounter with the images $[\ldots]$ momentarily aligns us with the originating perpetrator position [...]. Even if we begin to recoil once realizing what we are seeing, making sense of the image's denotation already aligns us with that perpetrating gaze" (850). This brings us back to Naidu's argument suggesting a complicity and shared responsibility between author and reader, with which I agree in principle. However, this does not apply to the examples that I have just discussed, because here Orford effectively prevents the reader from critically engaging with his/her complicity. Rather than giving the reader a chance to reflect on the problematics of what is being represented, Orford turns him/her into a perpetrator, too. As a consequence, the only ethical choice that a reader is given is simply to refrain from reading her novels - a choice that again forecloses critical engagement. As long as Orford renders the female dead body erotically charged and sensationalises women's pain, her and her readers' attempts to bear witness to women's traumas will be thwarted. Since the male gaze is aimed precisely at not seeing the double package of femininity and death, it is utterly useless as a form of ethical engagement with the female victim. As we have seen in Lorimer's and Nunn's depictions of female victims, there are ways of raising awareness of both female pain and the problematics of representing it in crime fiction. Orford, too, understands how to do this. 
While perpetuating phallocentric voyeurism, Orford employs various means to reflect on and disrupt this practice in her crime fiction. Again, Aaron's notion of ethical spectatorship helps to illustrate the point. For Aaron, the spectator is neither passive nor impartial, but complicit with and hence responsible for the representation of the socially unacceptable and the sufferings of others. Films and texts that allow for ethical spectatorship are "contra-disavowal" by adopting an "anti-forgetting strategy": "They deliberately break that cinematic contract between spectator and screen [...] by aggravating the act of 'artful forgetting' at the heart of the spectacle-real dynamic" (Aaron 2007, 92). Orford makes spectatorship as such an issue through the pervasive presence of film in her crime fiction. Clare's own documentaries, alongside the porn videos and strip shows, work to conscientise the reader of (her/his) spectatorship. Orford's novels also feature representations of pain and exploitation that are contra-disavowal, in Aaron's sense, in two distinct ways. First, Orford does allow female victims to speak for themselves at times - although not as often as Lorimer does - thus impeding "artful forgetting". Daddy's Girl is interspersed with the thoughts and physical experiences of the captured girl Yasmin (see, for example, chapters 15 and 26). Yasmin's voice is set apart by the use of italic print, visually signalling an interruption of the narrative flow and creating the impression of a voice that is independent of the narrator's, even of polyphony. In Water Music, Orford employs a similar technique, inserting the transcript of the testimony of a real-life victim who, much like her fictional protagonists Esther and Rosa, was buried alive underground $(187-189 ; 331) .{ }^{41}$ In a similar vein, Like Clockwork features fictional trafficking victim Nathalie Mwanga's verbal testimony, including both parts that she recounts in front of Clare's camera and parts that she decides to keep to herself $(38-41)$. The fact that we watch

41 When working on the same novel, Orford apparently deleted, or at least chose not to include, large sections written from Rosa's perspective. Her explanation for this decision illustrates both her awareness and the divergent ways in which she represents the female victim: "Rosa posed the problem of the absent female victim - the staple of so much crime fiction. I felt I had to imagine her fully and, in the earlier drafts, I had written several chapters from her point of view. So I got to know her and understand her by writing herby making her very much a real person who tries her best to survive what has happened to her. This did not work well for the tension in the way that I had structured the plot. It did not work for the revelation at the end as the mystery is unfolded very much from Clare Hart's investigative point of view. However, it meant that getting other characters to tell the story of Rosa was easy because I had written so much from her perspective. It was a matter of distilling that sense of her - and of her absence. A way, I suppose, of trying to work out how to solve the problem of the erasure of the female victims of crime" (Orford 2013a, par. 8). While I understand the genre's requirement for suspense, I would question the validity of Orford's last point. 
both Clare filming and asking questions and Nathalie "adjust[ing] her hair [...] [sitting] straight up in her chair and pull[ing] her skirt over her knees" (38-39) before answering in front of the camera reminds us that this is a performance and that we, like Clare, are spectators. ${ }^{42}$ In all these examples, we are given access to the female victim's voice and thoughts. This allows Orford to open up a space for her readers' own ethical reflections and, in so doing, to foster the reader's agency. By having the victim speak to the reader in the first person, Orford creates the effect of testimony, with the victim exposing her sufferings in a way that removes the safe distance between character and reader - almost with the assumption of a bond of trust being established, similar to the autobiographical pact.

For Aaron, these features are all markers of ethical spectatorship. A second contra-disavowal strategy to be found in Orford's fiction is what Aaron terms consistent "artful reminders" $(2007,94)$. When Clare and Charlie Wang visit the Winter Palace in Daddy's Girl, they are rendered as observers of and commentators on male customers observing and interacting with female sex workers in the club. Clare as focaliser of the scene contrasts the women's seductive behaviour with their blank eyes and likens a customer's "cupping the woman's breast in his hand" to a butcher who is "weighing fresh meat" (173). When a mesmerised Charlie breathes, "This is like a movie," Clare says matter-of-factly, "Not people you want to get to know, Charlie" (173). Clare's sardonic reminders turn this representation of female victims ${ }^{43}$ into a self-reflexive and thus ethical one. The sex workers' scantily clad bodies are just as sensationalised and sexualised as the dead female victims displayed on the Sea Point promenade in Like Clockwork, but they are pictured in this way for the gaze of the onlooking male customers only, not for Clare's benefit, or for the reader's. They are presented to us together with Clare's disapproving response, thus giving us clear ethical guidelines on how to react to the spectacle. ${ }^{44}$ An analogous scene in a strip club in Like Clockwork displays a quite different level of reflexivity. When Clare interviews Landman in his Isis Club and "[t] he lights [were] suddenly dimmed"

42 In an analogous scene in Daddy's Girl, we see only Clare's documentary film version of Pearl de Wet's testimony (35-37). With the production process by and large omitted, Pearl is rendered indirectly, making artful forgetting easier for us as spectators.

The sex workers are depicted as victims. They are immigrants who are dependent on their gangster owners and addicted to the drugs that they sell. This reminds us that sexual victimhood is implicated in wider forms of global commerce in the service of a violence that masquerades as business.

44 The same successful strategy is used in Water Music, when we watch the porn video featuring Rosa on Jonny's phone through Clare's eyes and are shown her disgusted reactions $(211-212)$. 
(154), she is released not only from her interview, but from her duty of functioning as an artful reminder to us as readers. Clare watches the strip show, which is rendered in explicitly erotic terms, completely fascinated over an extended period of time, until "Landman touched the inside of her knee. 'That is Justine. I see you like it [...]' " (155). It is only now, by qualifying the spectacle as a "degradation," that she dis-aligns herself - and us as readers - from the sexually predating male gaze that she has been adopting. After the interview, Clare feels both complicit with Landman's misogyny and defiled by her own sexual arousal (157). What we get here is first Clare's unethical disavowal - and, by extension, the reader's - and then her "artful reminder", which characterises ethical spectatorship. However, this reminder is belated and is further undermined by what follows: Clare's road home takes her "without thinking” straight into Riedwaan's bed, where his passionate love-making "obliterat[ed] from her mind what she had watched all evening" (157). We are left wondering whether Clare's act of self-protection is not obliterating her previous act of contra-disavowal along with it. As Naidu concludes on reading this scene, both Clare and the reader are being compromised here (2014, 76), I am not persuaded by Naidu's argument that Clare's belated artful reminder in the scene - which is subsequently "obliterated" - has the effect of encouraging reflexivity in the reader, but, in any case, self-reflexivity can cut both ways. As Aaron points out, it is "capable of being either conservative or transgressive" $(2007,94)$, and the "line between a representation perpetuating or critiquing conventional myths $[\ldots]$ is a thin one" (98). This brings me to the third type of representational practice that Orford employs: those instances in which she simultaneously both sacrifices the female victim in representation and exposes and contests the practice.

When Clare is close to solving the case of Suzanne's murder in Gallows Hill, she goes in search of Lilith, whom she knows to be in danger from her mother's killers. Once she is inside Lilith's house, Clare is guided to a curtained alcove at the end of Lilith's studio by the faint odour of blood:

Clare pushed the curtains aside and recoiled at the form sprawled on the floor, pale as marble. Lilith. Her lovely head turned away from the door where Clare had entered the room. Clare's eyes were led from the delicate shoulders, rib by rib, to the angle of her hip, the gentle slope of her thighs. The knees. The feet still in heels. Almost the pose of a reclining nude. Her limbs were small and compact, the hips flaring from a narrow waist, her breasts exposed. Above the gash of red lipstick, her face was wan, her hair matted. Blood pooled around her. Both wrists were slashed, with long deep cuts to the bone. 
Clare's slow gaze here in semi-darkness creates the dying Lilith as a piece of art - recalling the stock imagery of the beautiful "reclining nude" cast in "marble," imbuing her with erotic charge, setting her off against a dark pool of blood. Thus, step by step, she activates and reconstructs the aesthetic conventions that link femininity and death. Only after this long-drawn-out moment does Clare attend to Lilith's sufferings. She finally feels for her "moth-breath," diagnoses her as just alive and bandages her wrists (328) before she herself falls into the hands of the perpetrators. What is replicated and perpetuated here is the sacrificial male gaze on the dead/dying female body: the gaze that renders the woman invisible as a subject and distracts from her trauma, as Bronfen and Pollock maintain. Discussing Edgar Allan Poe's famous proposition that "the death of a beautiful woman is, unquestionably, the most poetical topic in the world" (1992, 59), Bronfen claims, "The equation between femininity and death is such, that while in cultural narratives the feminine corpse is treated like an artwork, or the beautiful woman is killed to produce an artwork, conversely, artworks emerge only at the expense of a beautiful woman's death and are treated like feminine corpses" (1992, 72-73). In Orford's text, Clare's prolonged predatory gaze both "kills" the beautiful woman that is Liliths and, by slowing down the narrative pace and creating suspense, serves to create the artwork that is the comforting detective novel. ${ }^{45}$ The absence of Orford's usual mission - Lilith is one of Orford's rare female victims who is not subjected to sexual violence corroborates the impression that Lilith is sacrificed for art's sake alone.

However, this is only one part of the story. We must not forget that, before sacrificing Lilith, Orford had Clare push the curtain aside, thus turning the alcove into a stage. Here, it can be argued, Orford breaks the contract with the spectator by self-reflexively framing the victim's sacrifice as an artistic performance - a performance that is followed by potentially self-reflective echoes of the sacrifice in various languages and cultural spheres. Riedwaan finds the dying Lilith later on and likens her to a "halaal lamb" (Orford 2011b, 341), while Gilles up on Signal Hill replies to Clare's reference to "[a] human sacrifice" with "Muti" and "muti murder" (346). ${ }^{46}$ In Like Clockwork, Orford uses a different strategy to a similar both/and effect. The prologue starts off with the as yet

45 By contrast, an analogous scene in Daddy's Girl is much more fast paced and refrains from sacrificing the violated victim in art. Here, Clare springs into action straightaway when she finds the dying Pearl in her house following a brutal assault by her father: "Pearl on the floor. Clare dropped to her knees, her face close to Pearl's. Still breathing. Maybe. She put her hands against her neck. The flicker of a pulse [...] Clare called an ambulance" (303).

46 "Muti" is derived from the Zulu noun "umuthi" and means traditional medicine. A "muti murder" refers to a murder with the purpose of acquiring body parts for use in muti (Oxford English Dictionary 2017). 
anonymous perpetrator (Kevin Landman) as focaliser and torturer of the as yet anonymous victim (Whitney Ruiters). We see him sadistically burn the palm of her hand with his cigarette and then arrange for her to be picked up by one of his partners in crime as a "[f]resh delivery" (2). After a change of scene that is not instantly recognisable as such, "[m]any hours later" we see the victim again, alone and naked, "huddled in the corner of a room, unaware of the unblinking eye of the camera watching her" (2). The focus is first on her physical pain, caused by various wounds, and then on her thoughts of revenge: "to survive, she thinks of ways of killing. The door opens. 'Dinner, sir,' announces the maid, transfixed by the image on the screen. A finger on the remote and the bruised girl vanishes" (2). It is only now, when we hear the maid's voice and follow her transfixed gaze to the screen, that we notice that we have actually been watching the victim Whitney in a film that the perpetrator Landman is watching on his screen. On the one hand, we are thus rendered as complicit spectators. On the other, the gaze that we have just been adopting is not merely exploitative, but empathic and empowering in its attendance to the victim's sufferings and her retributive agency. Orford here at once reproduces and contests the female victim's sacrifice. Bronfen's concluding remarks on the female dead bodies written by the women writers she examined can be applied to this third type of representational practice: "These narratives by women writers self-consciously install the cultural paradigm that links femininity with death in the same gesture that they critique it" (Bronfen 1992, 432).

Overall, reading Orford's Clare Hart series through the lens of the female victims, whose advocate Orford seeks to be, epitomises the complexities inherent in writing women's traumas, particularly if they ensue from sexual violence. Orford convincingly conceives of the investigative process as a form of addressing and working through the ongoing trauma caused by South Africa's pervasive culture of sexual violence. By turning her detective heroine Clare into a temporary victim who has the crimes that she investigates replayed on herself, Orford is able to change the outcome of this repetition. She repeats with a difference, in LaCapra's sense, and this difference opens up a political space. It is a space for female agency that variously resists, subverts or - as detective agency - restores the patriarchal order.

The same can be said of Orford's representational strategies, which reflect a similarly contradictory gender politics. Although at times she exposes and resists the practice of sacrificing the damaged female body anew in representation - a tactic that has long been employed to ward off both the horrors of death and the threats associated with femininity - on other occasions Orford reiterates and perpetuates it. This has the effect of undermining her feminist agenda and effacing the very pain of women to which she is intent on drawing 
attention. The serial nature of her crime fiction both calls for and enables varying, even experimenting with, ways of writing female pain and ethically engaging the reader/spectator in the atrocities playing out on the page. However, not all of these strategies do justice to the female victim or can be reconciled with the author's best intentions.

\section{5}

\section{The Female Victim: Conclusion}

The female victim, unlike the female detective or the female perpetrator, is a gender stereotype, so rewriting her and revising the ways in which she has been represented constitutes resistance from within the stereotype. This resistance strategy is fundamentally different from contesting the patriarchal script by "re-gendering" the protagonist as female, as it has as its starting point the reproduction and repetition of what it seeks to subvert and, possibly, transcend. In this respect, the process bears a striking structural resemblance to trauma work. Just as working through trauma may retain elements of acting out, when "working through" the stereotype of the female victim, writers can easily lapse back into "acting it out" and thus reinforce the status quo. None of the writers discussed here is entirely immune to acting out. Nonetheless, the female victims in Lorimer's, Nunn's and many of Orford's crime novels are a far cry from the stereotype of the passive, objectified and invisible female victim who caters to male desire and anxiety concerning femininity and death. This lends support to Priscilla Walton's claim that, whereas the media often obscure or distort the female victim, crime fiction provides a site where victims' stories can be told and issues of gender violence and victimisation explored (2013, 22). By engaging with female victims, the three South African crime writers examined here succeed in writing their stories. What is more, to a large extent they reframe and complicate rigid conceptions of female victimhood. This can be understood as a reaction to the perceived inadequacies of the TRC with regard to gender, a kind of "counter-narrative," as Kate Every puts it $(2016,35)$. The writers continue and complement the work of the TRC by retrieving the voices of women not just as secondary, but as primary victims, by emphasising the systemic nature and gender-specific effects of many of the violations that South African women have had to endure, and by highlighting not only women's victimhood, but their agency and ability to recover from trauma and to transcend the boundaries of the patriarchal laws that have so often have been enforced with violence against them. If violence against women, particularly sexual violence, is a message directed at men in order to produce male 
dominance, as Du Toit claims in her fourth frame (2014, 118), recovering the female victim brings her back into the conversation. This is an act of feminist resistance on the part of the authors that exposes the patriarchal nature of the colonial and apartheid projects in South Africa and their legacies for women.

Because these crime novels retrieve women's traumatic experiences in the South African past and present, while also rewriting the perception of them, I have read them as trauma novels that take a stance against real violence. Pitting the novels' overt political agendas against the more latent politics of their aesthetics, particularly the ways in which they represent the violated/ dead female body - White and of colour - has revealed that, to varying degrees, the conflicting pressures within the genre persist. And yet, the novels offer a number of successful strategies to counter those pressures. Lorimer is able to preserve the voice of her murder victim Boniswa via her emails. In this way, she renders femininity and women's traumas present, "audibly" but also visibly, by averting the potentially predatory gaze from Boniswa's violated dead body. Nunn does not avert the male detective's hegemonic gaze from her female victim Amahle's dead body, but she undermines and transforms it into an empathic one. By writing a heavily traumatised male detective who is also traumatically implied in the cases that he investigates, Nunn makes her detective see and point to, rather than divert from, women's sufferings and numerous survival strategies. Although Orford sacrifices some of her female victims anew in representation, limiting the political thrust of her novels, even she finds methods of contesting this practice. Notably, she allows some of her victims to speak for themselves, through, but also beyond, Clare Hart's documentary camera. She also self-reflexively stages practices of seeing the female body and their compromising effects, thereby creating awareness of the reader's potential complicity and space for the reader to reflect on his/her own response to violence against women. This array of techniques allows for a writing of the female victim that does her justice. Not only does it save her from being effaced in representation, but it enables a sustained focus on, rather than a diversion from, her trauma. Thus, it potentially contributes to a breaking of the cycle of violence in crime fiction.

In the first part of this study, I have shown what can be achieved both culturally and in terms of race and gender politics by rewriting the female victim in crime fiction - a task made more difficult by the genre's commercial nature - and why it is important for scholars to widen their focus to include the female victim as well as the female detective. Although so far I have examined the female victim in isolation from the female perpetrator, to some extent this distinction is artificial: both Nunn's and Orford's novels testify to the proximity 
of the two roles, showing how in certain circumstances female victimhood can lead to female vigilantism and perpetration. The figure of the female perpetrator and her function within the genre will be explored more fully in the following part. 